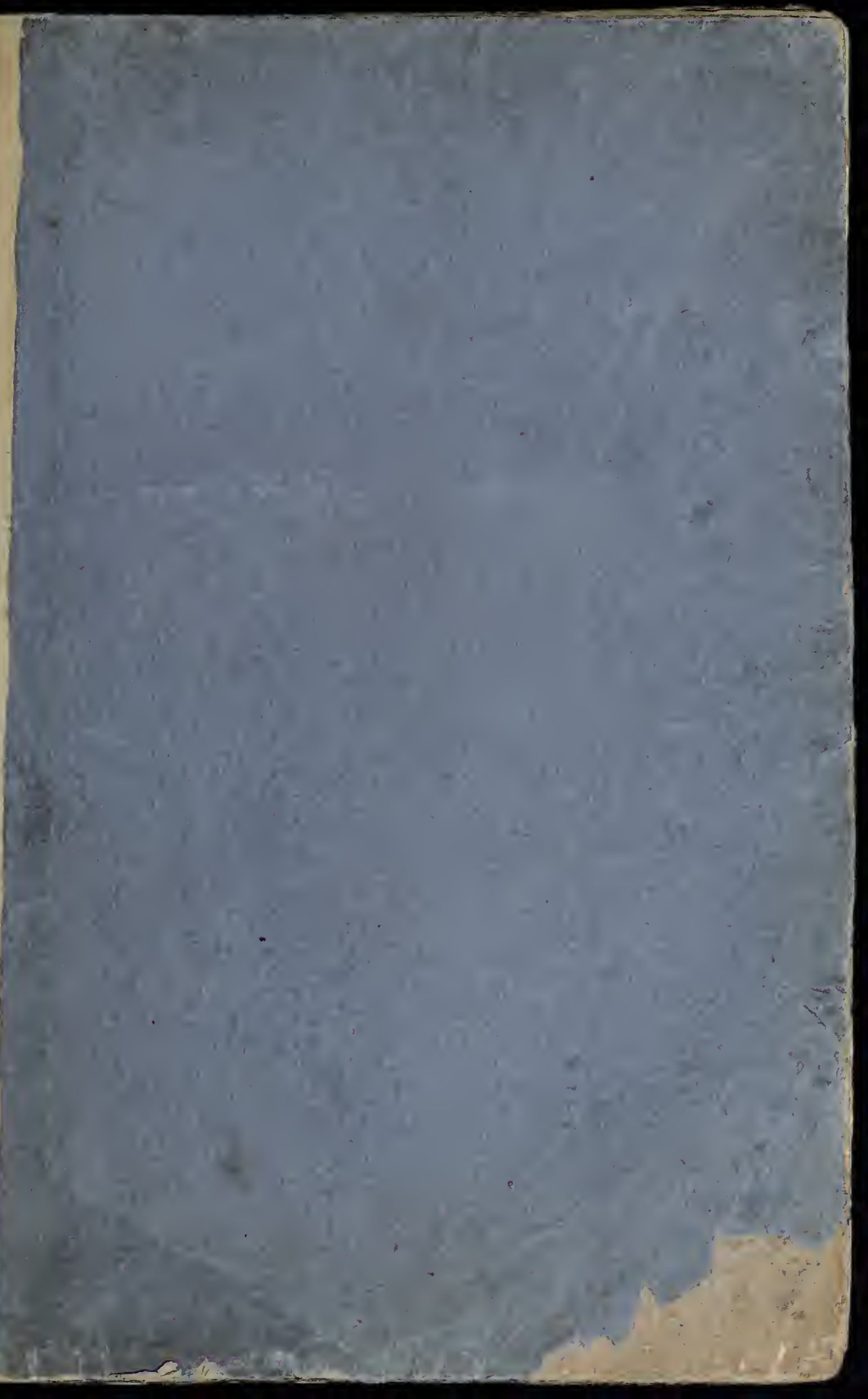


Lesithe Villara. Saina. 3

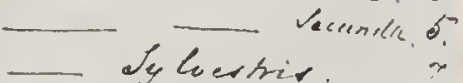
yecrtior. Qrtanditolic

- Viridis. II

- Palcustir. I3

- Prberita fficion. 15.

- Oton tuganis. 10

.... 21

- Aguntina sinor 23

- Rven maior. 25

$2 \pi$

- Pecacox....3t.

- Agustis. 33.

- Sentilier. 35 .

- Iracilis ... $3 \%$

- Pratherses. 39.

- Rebra. Nel

- Nariogata. 43.

- Rivalis. 45

- Jetian.

- Pacoura.

- Irecegivas. 59

Sycuestir. 33.

4

42 


\title{
MENTHE BRITANNICE:
}

\author{
A NEW BOTANICAL ARRANGEMENT
}

op

\section{THE BRITISH MINTS.}

ILLUSTRATED With 24 COPPER-PLATES.

BY W. SOLE. 


\title{
MENTHÆ BRITANNICA:
}

\author{
BEING A \\ NEW BOTANICAL ARRANGEMENT \\ OF ALL

\section{THE BRITISH MINTS} \\ HITHERTO DISCOVERED. \\ ILLUSTRATED WITH \\ TWENTY-FOUR COPPER-PLATES, \\ OF THE NATURAL SIZE, \\ Done from the Life by able Artists;
}

EXHIBITING A FIGURE OF EVERY DISTINCT MINT HEREIN TREATED OF,

Including all those enumerated by RAY and HUDSON;

TOGETHER WITE

SEVERAL NEW SPECIES HITHERTO UNNOTICED.

BY W. SOLE.

BATH, PRINTED BY R. CRUTTWELI.

$$
\text { AND SOLD BY MESSRS. }
$$

WHITE, PLBBT-STREET, LONDON; BULL AND CO. AND J, BARRATT, BATH; GILBERT, DUBLLN:

HANWELL, OXFORD; AND HODSON, CAMBRIDGE.

1798. 



\section{PREFACE.}

$\mathrm{IT}_{\mathrm{T}}$ is well known and agreed to by Botanifts, that the Mints ftill remain in great confufion and obfurity, owing chiefly to the fcarcity of good and faithful figures; and it is wonderful, amidft all our modern improvements in Botany, that no new plates of this very ufeful and beautiful tribe have been given, at leaft none that are capital; yet fuch is the intricacy and fportivenefs of this family, that it is impoffible for a verbal defcription alone to define them without the aid of juft and accurate figures to refer to. Perhaps the reafon why we have fo few of thefe, may be owing to the difficulty, labour, and tedioufnefs, in the execution of them, their flowers being fo numerous, and their component parts fo minute.

Fusch1us's plates, altho' they are in general rude and Gothick, correfponding to the times in which he lived, are fome of them very good, particularly his $M$. Hortenfis prima, our Sativa; and his $M$. Hortenfis fecunda, our Rotundifolia. His other three are but indifferent, I might fay bad.

JoHn BAUHine's figures are on too fmall a fcale to convey any proper idea of the plants, excepting only his Mentaftrum gravi odore, which is indeed a mafter-piece of thofe times, and worthy of admiration; and perhaps not to be excelled by artifts of the prefent day. 
Mathiolus alfo has a neat figure of Calamintba aquatica, our Arvenfis; and LOBEL has another of the fame, but from a different habitat, which has equal, if not greater merit. On the other hand, LoBEL's Mentbaftrum (evidently intended for our Villofa) is fo ambiguous, that fome authors have made it their Mentbaftrum longifolium, and fome again their Menthaffrum rotundifolium.

RAY, in his Cat. Plant. p. I98, has the following ftricture on this figure, quoting it from GERARD and PARK1Nson, (which are both copies of LOBEL) to his Mentbaftrum longifolium:- " Figure enim nullo modo "conveniunt;"-and then immediately after quotes the fame figures to his Mentbaftrum rotundifolium with an interrogation, being very doubtful which they are meant for. And what is rather pleafant, HrLl has copied it in his plates with this plain Englifh title- "HORSE-MINT;" forgetting to tell us whether long-leaved or round-leaved horfe-mint.* However, it is plain that it is meant for the long-leaved, by the deep faw-teeth of the leaves; for their Mentbaftrum rotundifolitun (Sylv. noft.) is crenated rather than ferrated.

Fuschius's figure, copied by J. Bauhine, is as bad, if not worfe, than LOBEL's. MORRIson's figure is fomething better, but Mrs. BLACKwELL's is very indifferent.

* I would not be underftood as implying any cenfure on HiLr, as he was in my opinion the beft Englifh Botaniff of his time, and, had he applied himfelf to the fubject, was well qualified to have explained it; but as he thought it perhaps an object which was not likely to attract notice, he followed the confideration of his Bardana, which eventually proved moft productive. He was certainly a great genius, but his imagination was diverted by following too many purfuits.

Added 
Added to the inaccuracy of the plates now extant, another caufe contributes no fmall matter to the prefent confufion, that is, the deficiency in number; LinN\&eus having allowed us but ten mints, whereas our immortal RAY, after having defcribed no lefs than fixteen, with all that pleafant candour fo peculiar to him, finifhes the fubject with this remark-_" Mentburum valde ferax ef Anglia noftra, nam prater Jpecies de novo " bic additas, quatuor alia peculiaribus nominibus recenfentur a MERRETTO " in Pin. et plures prater bas tum a D. BUDDLE, tum a D. RAND obfervata "funt. Sed cum de iis nobis nondum fatis confet, ulteriori eas obfervationi "relinquere neceffe babuimus." This is a fufficient proof that $\mathrm{RAY}$ thought the field of Englifh mints far from being exhaufted.

TOURNEFORT feems to have found all RAY's plants in France, and defcribes them with little or no variation.

Sir Joun $\mathrm{H}_{1 \mathrm{LI}}$, in his $B . H$. has only copied RAY, and thrown no new light on the fubject. Our late eminent Englifh botanift, $\mathrm{Mr}$. Hudson, whofe lofs will be long regretted, appears to have been well acquainted with all RAY's plants; and, obferving that LiNN re us had totally unnoticed many of them, and unwilling to have them left in ob-i fcurity, has, in his fecond edition, introduced them as varieties, fome in one place, and fome in another. The attempt was certainly laudable, but it was not fuccersful, having tended only to increare the entanglement.

Upon the whole, then, it is very obvious to all who are any ways converfant with the fubject, that an entire new fet of good plates of the mints is much wanted; nor, indeed, can any frefh illuftration of them be given

without; 
without; and, as I have always been of opinion that good plates are injured by colouring, I have endeavoured to procure fuch plates as need no colouring; my intention in this effay being not only to give fuch plates as will bear future references, but, at the fame time, to harmonize all the prefent difcordant quotations that fo often occur both in LiNN $x$ US and Hudson, and to adduce every quotation in its right place, that the tyro may be no longer puzzled by contradictions; but, on the contrary, be enabled to find out his plant quick and to a certainty; for which reafon I have, in all the abftrufer mints, given a difcriminating characteriftick, to facilitate his refearch, and to prevent his remaining in doubt.

I have nothing to add, but that I win this humble attempt to illuftrate the mints, may ftimulate fome abler Botanift to purfue the fubject, and render it more compleat. Having no coadjutor to affift me, it is probable there may be many errors and mittakes; and I fhall be very thankful for any communications that may be made to me, pointing them out; that, in cafe a future edition fhould be called for, I may be enabled to make it more perfect; unlefs (as I hinted above) an abler hand fhould take up the fubject.

W. S. 


\section{MENTHÆ BRITANNICE.}

SERIES PRIMA.

\section{MENTHÆ SPICATÆ.}

I. Mentha villofa prima.

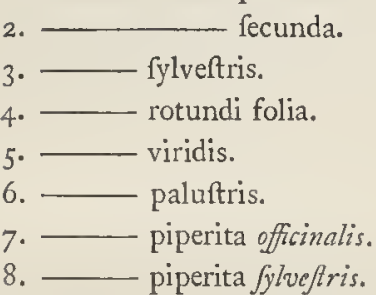

To render the Mints lefs difficult to find out, Linnæus has very judicioufly divided them into three feries or fortments, viz.

I. SPIKED Mints.

2. Round-headed Mints.

3. Whirled Mints. 


\section{BRITISH MINTS.}

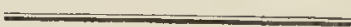

SERIES THE FIRST.

\section{SPIKED MINTS:}

Confifting of fuch Mints as produce their flowers in long flender fpikes at the tops of the ftalks and branches. This feries contains the following eight Mints:

r. Long-leaved Horfe-Mint.

2. Common Horfe-Mint.

3. Strong-fcented Mint.

4. Round-leaved Mint.

5. Spear-Mint.

6. Marfh-Mint.

7. True Pepper-Mint.

8. Wild Pepper-Mint. 


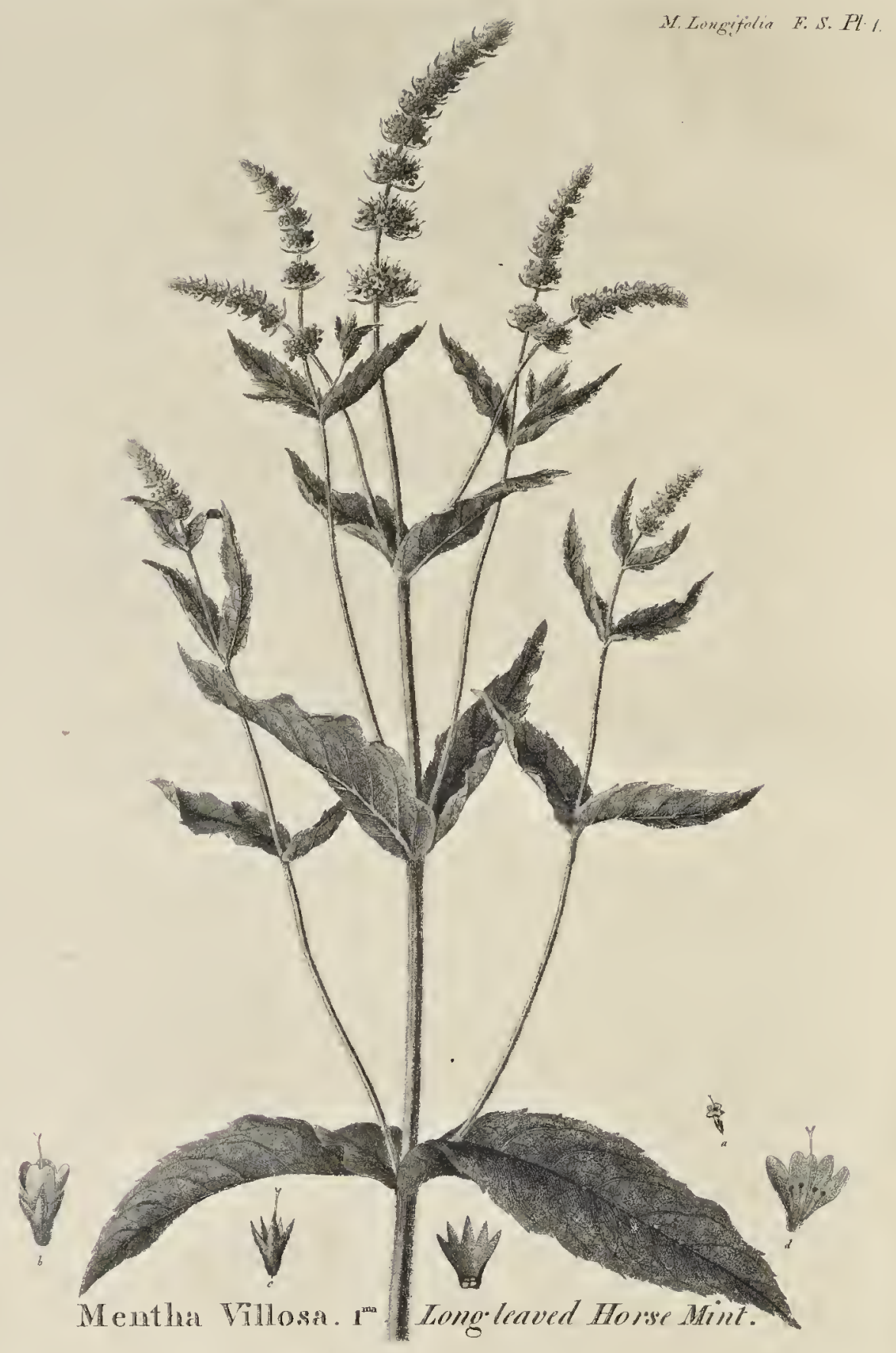

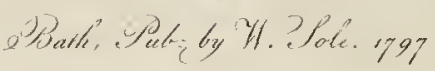


Explanation of the small Figures at the bottom of the Plates.

a The Bloffom, Calix, and Style, of their natural fize.

$b$ The fame magnified.

$c$ The Calix magnified.

d The Corolla magnified and laid open, to difplay the length of the Stamens.

$\varepsilon$ A Calix magnified and laid open, to exhibit the four naked feeds at the bottom of it. 


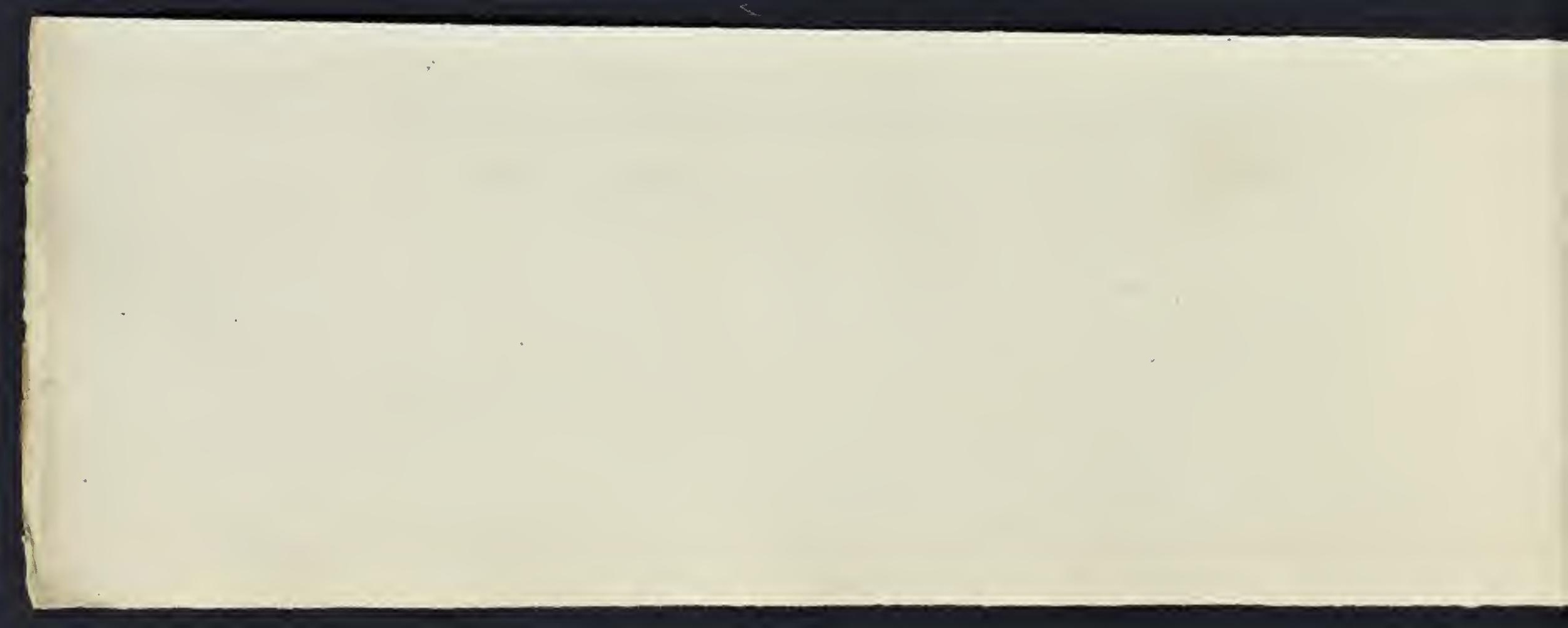




\title{
r. MENTHA VILLOSA PRIMA.
}

\author{
[Long-leaved Horfe-Mint.]
}

Mentha fpicis oblongis, bracteatis, foliis feffilibus lanceolatis ferratis acutis tomentofis incanis, venulis reticulatis, ftaminibus corolla brevioribus; odore hircino. Difc. bracteis longis.

Mentaftrum. Fufch. p. 295, ico.

Menthaftrum fpicatum folio longiore candicante. F. B. iii. p. 222. ico. Fuf.

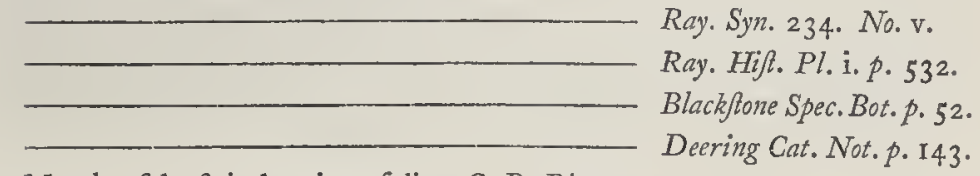

Mentha fylveftris longiore folio. C. B. Pin. 227.

Mor. H. O. i. p. 368 , ico.

Map. Pl. Alfat. p. 193 .

Mentha. xvii Tourn. Infit.

Mentha floribus pallidis folio longo candicante. Hil. B. H. 353 .

Mentha fylveftris. Lin. Sp. Pl.p. 804. (folia albida.)

Habitat in paluftribus et fofis, fed rarius. 


\section{r. LONG-LEAVED HORSE-MINT.}

THIS is a tall elegant plant, ufually growing four feet or more in height; its leaves are long, acuminated, ferrated and feffile, embracing the ftalk, they are woolly and hoary on the under fide, and green and hairy on the upper fide; the veins of the leaves form a beautiful net-work, equally vifible on both fides. The ftalks are quadrangular, hoary, and upright, terminating in neat flender fpikes of flowers, compofed of fmall rundles, with long, narrow, confpicuous, bracteal leaves under each rundle. The flowers are very fmall for the fize of the plant, and are of a beautiful pale lilac colour. The ftamens are always thorter than the flower, and cannot be feen but when the bloffom is quite expanded.* It bloffoms the laft week in July, and the whole plant has a difagreeable goatifh minty fmell.

It is met with in ditches under hedges, and about mill-dams, and in obfolete water-courfes, but is not common. I obferved it in a lane going from Littlebury to Lord Howard's on the left hand, and in a mill-dam at Matlock; and the wild fpecimen from which this plate was done, I found in a clofe at Box, Wilts, called Box-Lays.

\footnotetext{
- Linnaus and Haller both make it a leading feature in this plant, that the ftamens are longer than the flower; but as I have never yet found it fo, either in its wild or cultivated fate, I durft not adopt either of their defcriptions.
} 
Pl: 2.

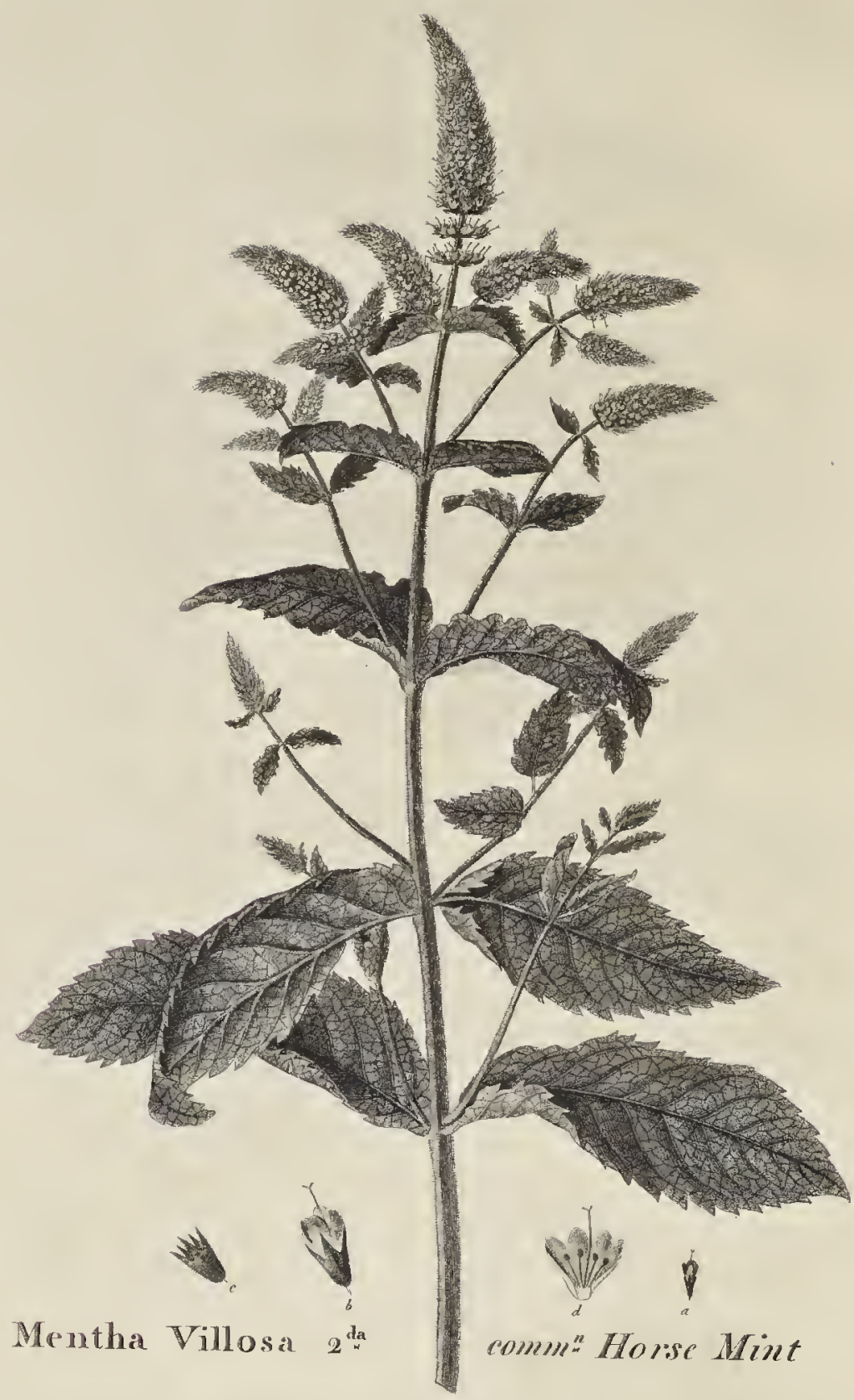

TR Rabeins. De

Whath. Opulic by th. Pile. 1797

Erbtert St 


\section{MENTHA VILLOSA SECUNDA.}

Mentha fpica oblonga, foliis feffilibus, ovato-lanceolatis acutis villofis.

Hud. Flo. An. p. 259.

Quibus notis addi potest, ftaminibus corolla brevioribus.

Menthaftrum. Matb. p. 527. ico.

Mentaftrum. Lobel. icon. p. 509.

Mentaftrum. Ger. em. p. 684. icone Lob.

Mentaftrum hortenfe. Park. $p \cdot 33$. ico. Lob.

Mentha fylveftris longioribus nigrioribus et minus incanis. C. B.Pin.p.127. Mentha fylveftris candicans odore fativi. Doody.

Mentha fpicata. ii, iii R. Syn. p. 233, 234 .

Mentha. xv Tourn. Inft.

Menthaftrum. Blackwell H. p. 292. ico.

Mentha. x, xi Hill, B. H. p. 354, 355 .

Difc. Spicis denfioribus obfolete bracteatis, foliis fuperne glabrioribus, inferne villofis; caule rubefcente, odore $M$. viridis.

Habitat in locis uliginofis. 


\section{COMMON HORSE-MINT.}

THIS Mint grows about three feet in height, the ftalks are quadrangular; hairy, and green, turning reddifh as the fummer advances; they are moderately branched, which, as well as the ftalks, all terminate in oblong thick-fet fpikes of flowers, of a white palifh-red colour; the ftamens of which are always thorter than the bloffom. The leaves are feffile, oblong, and pointed, deeply fcerrated round the edges, and are of a blackinh-green colour on the upper fide, and hoary and villofe underneath; they are deeply furrowed or wrinkled, fomething like green fage. The whole plant fmells much like fpear-mint.

This plant differs from the foregoing, in its leaves not being near fo hoary, long, and acuminated; in its fpikes being fhorter and more denfe, infomuch, that the bractea appear like hairs between the flowers, not long and foliaceous as in that, and does not bloffom before the middle of Augurt; yet it is probably only a variety of the foregoing: but as it has, after the cultivation of it for more than twenty years in my garden, maintained its diftinctions, I thought it beft to give a figure of it; being of opinion, that where varieties are permanent, it is better to defcribe them apart, than to crowd them in with a $\beta . \gamma . \& \mathrm{c}$. For it is very confufing to a tyro in particulat, to fee in the fame plant one author defcribing it with long acuminate hoary leaves, fmelling like a goat, \&cc; and another faying, the leaves are broad and fmooth; and a third faying, it finells finely of fpearmint:- - he of courfe becomes puzzled, and gives the matter up. I have moreover the fanction of Ray, Tournefort, and Hill, who have all acted as precedents in the fame manner.

This variety is much more common than the foregoing, being to be met with in moft home-clofes, about farmers' bartons, and fuch places. I obferved it by the water-fide at Bottifham-Load mill, Cambridgefhire, and in a home-clofe of an inn at Hillington, Middlefex, and frequently under hedges in Hertfordhire.

This and the preceding both poffefs fimilar qualities to the $M$. fylvefiris, and have always been promifcuoufly ufed for that; but the powers of the fylveftris being much more eminent, it ought always to be preferred, whenever it can be procured. 


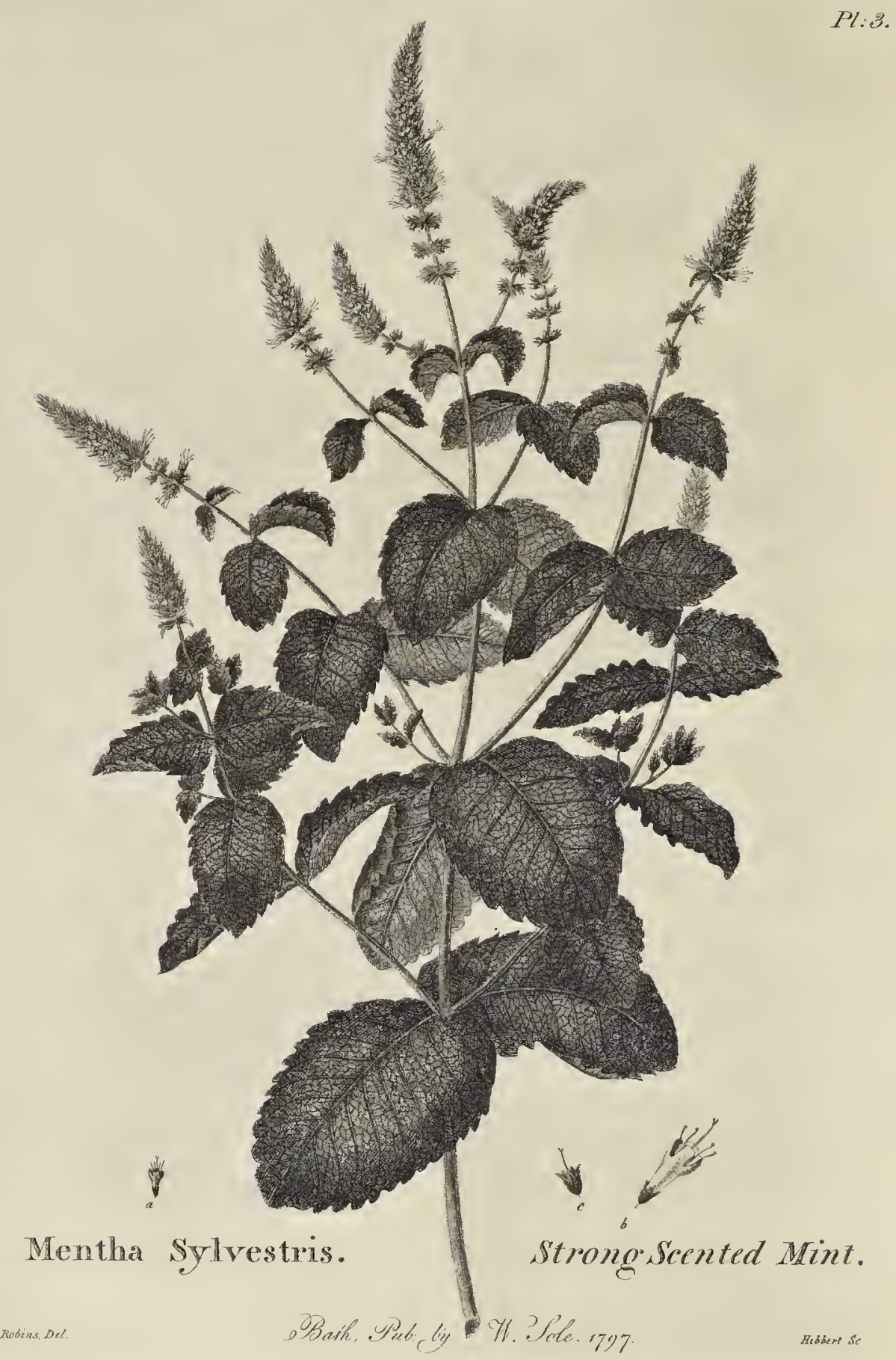




\section{MENTHA SYLVESTRIS.}

Mentha fpicis oblongis, foliis rugofis feffilibus lanuginofis crenato-dentatis, inferioribus oblongis obtufis, fuperioribus rotundatis, venulis reticulatis, ftaminibus corolla longioribus.

Mentha fylveftris prima rotundiore folio. C. B. Pin. $p .227$.

\section{Map. Alfat. p. 193 .}

\section{Tourn. Inft. No. i.}

Menthaftrum folio rugofo rotundiore, fpontaneum, flore fpicato, odore gravi. F.B.Hift. iii. p. 2 I g. cum ico. praftantifima.

R. Syn.p. 234.

Deer. Cat. Not.p. 144 .

Blacks. Sp. Bot.p. 53 .

Hill. B. H. p. 353 .

Menthaftrum valde ramofum flore violaceo rubro. Mer. Pin. p. 77.

Mentaftrum rotundifolium minus. Park. $p \cdot 34$.

Menthaftrum. No. ix. Mor. H.Ox. p. 368.

Mentha rotundifolia. Lin. $S p . P . p .805$.

Hud. F. A. p. $25 \mathrm{I}$.

Menthaftrum officinale. Mat. Med. Antiq.

Habitat in aggeribus et ruderatis.

Nafcitur in locis uliginofis.

f Menthaftrum niveum anglicum. Lobel. icon. p. $5_{\text {ro. }}$

Ger.em.p. 684. ico. Lob.

Menthaftrum fpicatum, folio crifpo, colore partim albo, partim cinereo, vel virente. F. B. iij. p. 219.

Mentha ficata folio variegato. C. B.Pin. p. 227.

Tourn. Inft. No. xii. 


\section{STRONG-SCENTED MINT.}

THIS plant grows from two feet and half to three feet in height; its ftalks are quadrangular, hairy, upright, and very much branched with flowering-fprigs clegantly difpofed, each fprig generally terminating in three (and fometimes more) beautiful flender fpikes, of whitifh-red flowers, which are fo expanded that the ftamens with their little red anthers or chives are always in fight, and are longer than the flower; the leaves are wrinkled and downy underneath, and are nleeker and of a dark green above, the veins are neatly reticulated, and obvious on both fides; the lower leaves are oblong and blunt, the upper leaves are roundifh; they are feffile, and are crenated rather than dentated. It has a very ftrong volatile mixed fmell of volatile falt of amber, camphor, and mint.

This is the true Menthaftrum, or wild Horfe-Mint of the fhops.

It is now and then found spontaneous in muddy places in high moors; for instance, on a common at Elsmoor, Shropshive, but it is very rare: yet as an honourable relict of ou. renerable Gothick ruins, it is rery common; as in a close called the Abbey-Wraren, at Ifinton-Abbey in Somerset; in the environs of Abbey-Tintern, S. Wales; at RaglandCastle, ditto; in a close called the Abbots-Garden, at Glastombury-Abbey; in a high meadow near Berkeley-Castle; at Irenlock-Abbey, Salop; at the ruins of an old abbey, or fastle, (I forget which) near the strand at Ilollyrell; and obseried by Mr. Blachstone, in Marefield church-yard, and by Di. Deering, in the neighbourhood of Nottinghan-Castle.

Thefe habitats fufficiently evince, that the powers of this plant were well underftood by the Monks, who were in their days the principal phyficians; and this knowledge (as foon as literature begin to revive in Europe) was eafily acquired from the works of the Arabian phyficians, particularly Rhafes, who made great ure of this plant. Be this as it may, it certainly is a plant of great virtue, and deferves to be better known than it is at prefent, being an excellent cephalic, antihyfteric, ecphractic, and cardiac fimple. I have found it of great ufe in cafes of epilepfy, and chlorofis; the latter cafe it moft commonly cures in two or three months. I cannot fay it has ever cured epilepfy, but it wonderfully refrefhes the brain, reftores the memory, and takes off the dull ftupid languor occafioned by thofe fits.

My mode of giving it is this:-Take sir arachms of fine powder, made from the green leave's and flower spikes, hastily dried, and with a sufficient quantity of syrup of orangepcel make an electuary; the quantity of a nutmeg to be taken morning, noon, and night, washing it down with a wine gluss of tea made with the same green herb in summer, and of the dried herb in weinter. In all cases before $I$ enter upon the ase of it, I premise an imetic of Ipecacuanha powder, and a scruple of Pil. Rufi, in four pills, to be taken after the emetic the same night. 



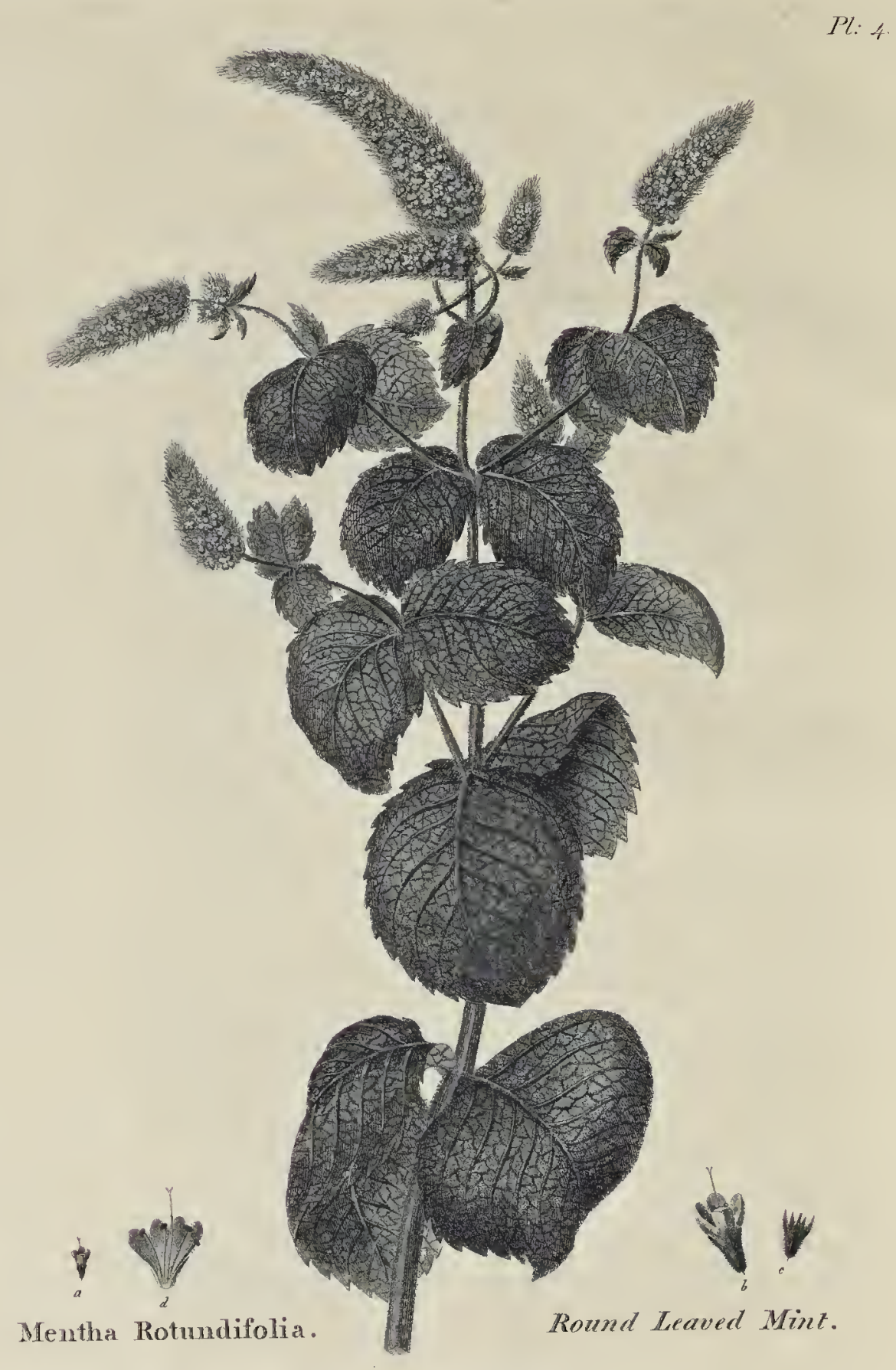


4. MENTHA ROTUUNDIFOLIA.

Mentha fpicis oblongis denfis; bracteis longis filiformibus; floribus rubris, foliis feffilibus fubrotundis rugofis dentatis villofis, nervis tranfverfis, venulis reticulatis, ftaminibus corolla æqualibus, caule erecto hirfuto, Menthæ viridis odore.

Mentha hortenfis. ii Fufch. ico. bon.

Mentaftrum fpicatum cultum, folio rotundiore rugofo. 7. B. Hifl. iii. p. 218.

Mentha rotundifolia fpicata altera. C. B. Pin.p. 227.

Sifymbrium hortenfe. Matb. p. 378. ico. Fufcb.

Sifymbria Mentha agreftis. Lob. icon. p. 508. ico. Fufch.

Mentha fpicata altera. Ger. em.p. 68 r. ico. Fufch.

Mentha fylveftris rotundiore folio, purpureo flore. Tourn. Injf. No. ii.

Reperitur in aquofis in Cantio et Effexia, fed rarius.

Augufto foret. 
THIS wild Mint grows to the height of three feet and upwards; its ftalk is quadrangular, large, very hairy, upright, and not much branched, terminating in very large thickfet fpikes of flowers of a bright-red colour; the bracteals are like hairs, and project fo much above the flowers as to give the fpike a ftrong refemblance of a fox's tail.

The leaves are feffile, almoft round, and deeply ferrated; they are of a dark-green colour, wrinkled, and hairy; the nerves of the leaves run tranfverfely, and the veins are reticulated; the ftamens with their beautiful red anthers, being equal to the bloffom in length, appear in fight when the flower expands.

The fmell of this plant refembles that of fpear-nint, but is not fo fragrant.

I believe this plant is very rare, as I have never yet met with it fpontaneous. It was given me eighteen years ago by that very eminent botanift, W. Aiton, efq; (late botanic gardener to his Majefty) who, at the fame time, informed me, that it had been fent to him by a correfpondent who had found it both in Kent and Effex.

It flowers in Auguft. 


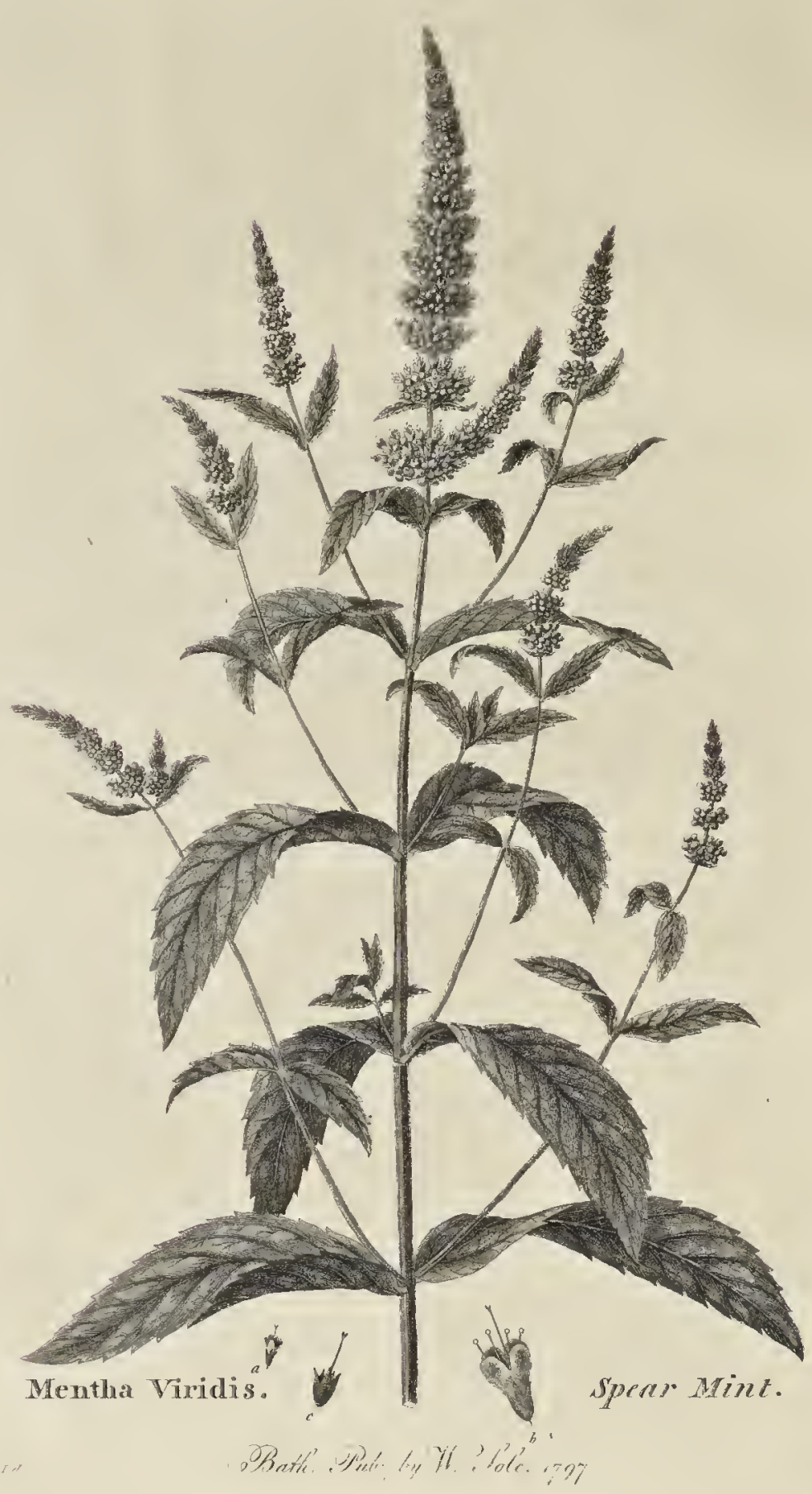

Pl:5. 


\section{MENTHA VIRIDIS.}

Mentha fpicis oblongis, foliis lanceolatis nudis ferratis feffilibus, ftaminibus corolla longioribus. Lin. Sp. Pl.p. 804 .

Mentha fpicis folitariis interruptis, foliis lanceolatis ferratis feffilibus.

Hort. Clif. p. 306 .

Mentha prima. Math. p. 506. ico.

Mentha hortenfis. iii Fufch. p. 29o. ico.

Mentha fpicata, folio longo, acuto, glabro, nigriore.

F. B. Hiff. iii. p. 220. ico.

Mentha romana officinarum, five præftantior anguftifolia. Lobel.icon.p. $5 \circ 7$.

Mentha romana. Ger. em. p. 680. ico. Lob.

Mentha anguftifolia ficata. C. B. Pin. p. 227.

R. Hiff. Pl. tom. i. p. 532 .

Tourn. Inf. M. xiii.

Mor. H. O. feEt. xi. tab. vi. f. I.

Lewis. Mat. Med.

Mentha fpicata vulgaris. Hill. B. H. p. 353 .

Mentha fativa. Blackwell. H. p. 2go. ico.

Mentha viridis. Hud. F. A. p. 250.

Latioribus aliam, aliam angufiffmis et longiffmis foliis in bortis obfervavimus. C. B.

Habitat in aquofis et ad ripas fruirorum.

Augufto floret. 


\section{SPEAR-MINT.}

THIS plant grows about three feet in height; its ftalk is quadrangular, upright, fmooth, and of a bright green colour, being neatly branched with upright fprigs, which terminate in elegant long fpikes of flowers, which are of a bright-red colour, dotted here and there with white fpecks in the infide; the ftamens, tipped with beautiful red knobs, are longer than the bloffom.

The leaves are long, narrow, acuminated, and deeply ferrated, and fitting on the ftalk; they are of a grafs-green colour, and perfeetly fmooth on both fides; the nerves are white, and the veins obfcurely reticulated; the whole plant has a moft fragrant and refrefhing fmell. Its red bloffoms, fmooth leaves, and eminent ftamens, fufficiently diftinguifh it from the villofa's.

Ray and Hill, neither of them finding it wild, treat it as an exotic; but our great Mafter, Linnæus, boldly fays, babitat in Anglia; and Hudfon has quoted feveral habitats in his ingenious work Flo. Ang. and I have found it fpontaneous in a common between Glaftonbury and Wells; and the plant which produced the fpecimen for this plate, I brought home ten years ago from a wild habitat in the meadows four miles out of Bath, where it flourifhes to this day in an old water-grip, intermixed with $M$. aquatica, \&c.

It alfo grows in various places by the fide of the Avon between Bath and Kelfton,_- It flowers in Auguft.

The virtue of this excellent plant, as a cephalic, stomachic, and febrifuge, are so well established by the concurrent testimony of many ages, as to maintain its consequence and repute even at this time, when herbs in general are so unfortunately, and, I may say, unjustly repudiated, that it needs not to be enlarged on here. 



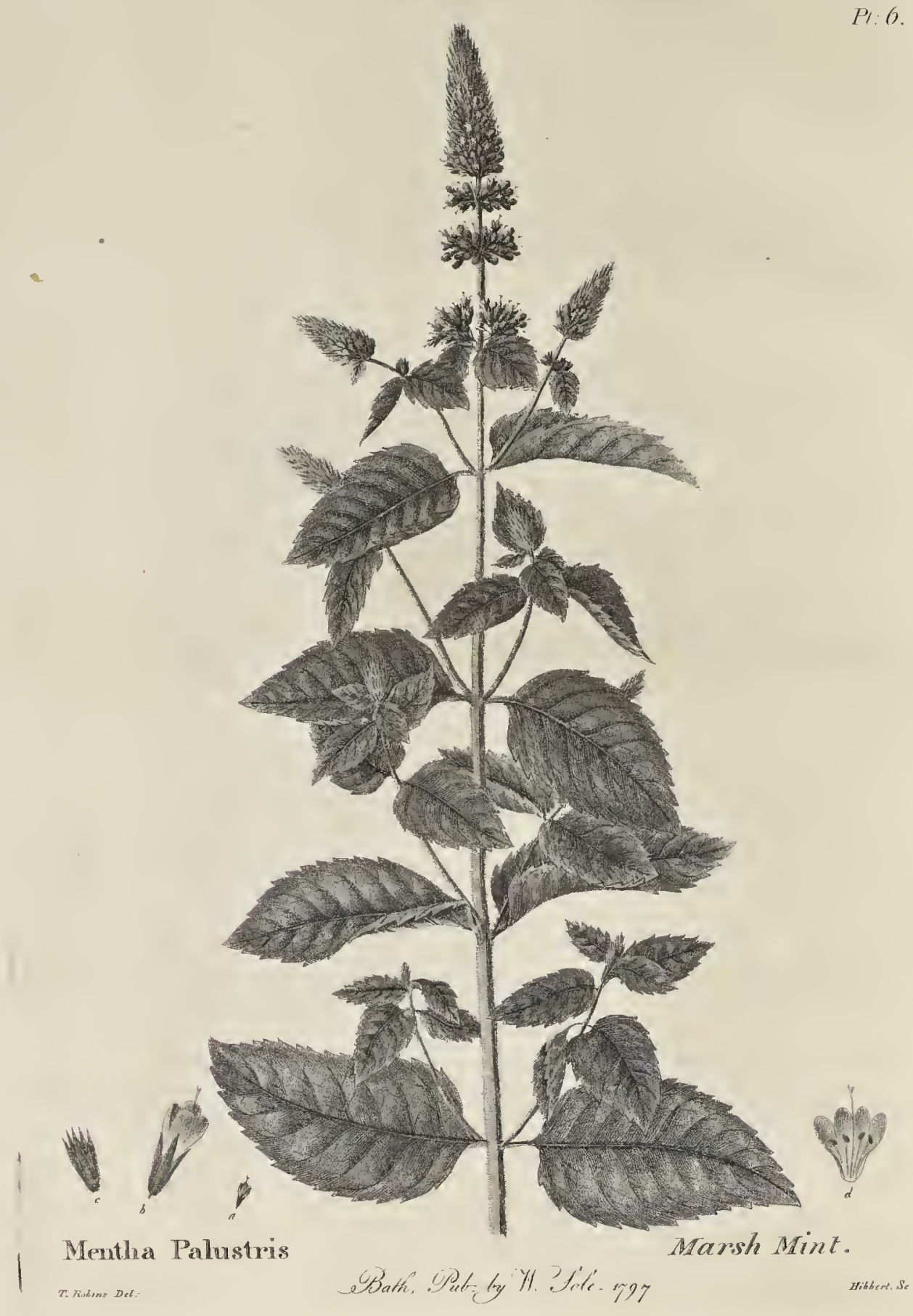


Mentha fpicis oblongis interruptis, foliis-latis ovatis acutis, ferratis, hirfutis, inferioribus oblongis; nervis rubefcentibus; ftaminibus corolla brevioribus; caule erecto hirfuto; odore hircino.

Mentha paluftris folio oblongo. C. B. Pin.p. 228.

Menthaftri aquatici genus hirfutum f́pica latiora.

Mor. H. Ox. p.369. fect. xi. tab. vii.f. 4 .

F. B. Hift: iii. p. 222. ico.

R. Syn.p. 234.

Calamintha iii. Diafcoridis Menthaftrifolia aquatica hirfuta.

Lob. icon. p. $5^{10 .}$

Menthaftrum minus. Ger."em. p. 68 5. ico. Lob."

Mentha xviii. Tourn. Inft.

Mentha foliis cinereis latioribus; fpica craffa. Hill. B. H. p. 353. M. xii.

Mentha fylveftris, $\beta$. Hud.F. A.p. 251 .

Habitat in fofis et paludibus.

Floret in Septembri. 
THIS Mint grows about three feet in height; its ftalk is quadrangular, hairy, upright, and but little branched; of a brownifh red colour, terminating in three broad fpikes of flowers of a pleafant red colour; the upright fpike being much larger than the collateral ones; the ftamens are fhorter than the bloffom, and hid from view.

The leaves ftand on footftalks; they are broad, hairy, ferrated, and pointed, and are of a greyifh colour; the lower leaves are oblong, but from the middle of the ftalk upwards they are ovate.

The whole plant has a goatifh-minty fmell.

It grows in old ditches at Glaftonbury, Wedmore, Birtle, and King'sSedge moors, Somerfet, plentifully.

It does not blow until the beginning of September, and fometimes later. 



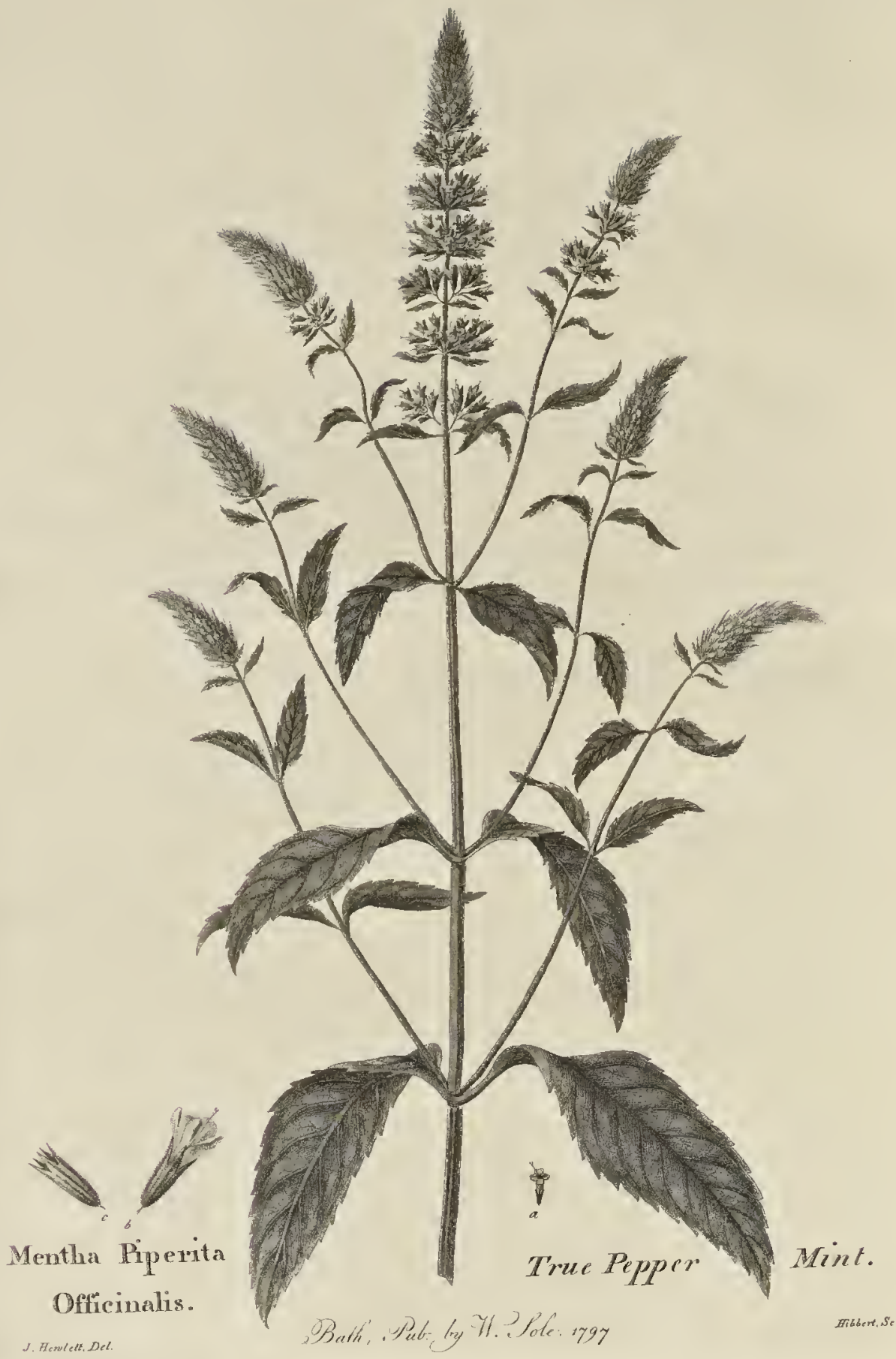


7. MENTHA PIPERITA OFFICINALIS.

Mentha fpicis oblongis interruptis, foliis lanceolatis glabrioribus argutè ferratis petiolatis, ftaminibus corolla wquantibus caule erecto fufco, odore piperis gratiffimo.

Mentha faxifraga anguftiore folio, fpicato, fapore acri fervido.

Pluk. Alm. p. I2g.

Mentha piperata acuta. Petiv. H. B. tab. xiii. $f$. ro.

Pepper-Mint with acuminated leaves. Lewis. Mat. Med.

Mentha piperitis. Blackwell. H. p. $29 \mathrm{I}$, ico.

Difc. Floribus fpicatis foliis lanceolatis.

Nafcitur in locis udis et aquofis.

Augufto fioret.

Fis Menth. pip. fylv, Vide Tab, xxiv. 


\section{TRUE PEPPER-MINT.}

THIS plant grows from three feet to three and a half in height; its ftalks are fquare, firm, upright, not much branched, and of a brownifh red colour, terminating in beautiful long fpikes of pale-red flowers; the three or four lowermoit whirles are interrupted, or fomewhat diftant, in the fame manner as in the fpear-mint; the ftamens are juft equal to the bloffom, and in fight when that is expanded. The leaves are long, narrow, acuminated, tharply ferrated, ftanding on footftalks, and are of a very dark-green colour; and when viewed on the under fide through a common pocket magnifying-glafs, in the fun or by candle-light, innumerable bright filver fpangles are difplayed all over the furface, which perhaps is its effential oil. All the Mints exhibit fomething of this kind, but none in fo eminent a degree as this does. The calix is ftill fuller of thofe fpangles than the leaves. I conclude it is from thefe fpangles or gems, (whether they be effential falt, or effential oil of the plant, let better judges determine) that it derives its virtues in cafes of ftone and gravel; for which purpofes, in Plukenet's time, it was in fo high efteem as to gain the title of SAxifRAGA; and its fingular efficacy as a carminative is well known in all families.

This plant grows fpontaneoufly in a fwampy place on Lanfdown called the Wells, it being the fpring-head of Locks-brook. It is alfo found by the fide of the Avon in Newton-Mead.

The whole plant has a very grateful poignant tafte and fmell of pepper.

It blows in the middle of Auguft. 


\section{MENTHÆ BRITANNICA.}

SERIES SECUNDA.

MENTH艮 CAPITATÆ, five SISYMBRIA.

1. Mentha piperita vulgaris.

2. —— odorata.

3. - aquatica minor.

4. —— aquatica major. 


\section{BRITISH MINTS.}

SERIES THE SECOND.

\section{ROUND-HEADED or WATER MINTS.}

Confifting of fuch Mints as produce their flowers in round heads at the tops of the ftalks and branches. This feries contains the following four Mints:

I. Common Pepper-Mint.

2. Burgamot-Mint.

3. Leffer Water-Mint.

4. Great Water-Mint, and its varieties. 


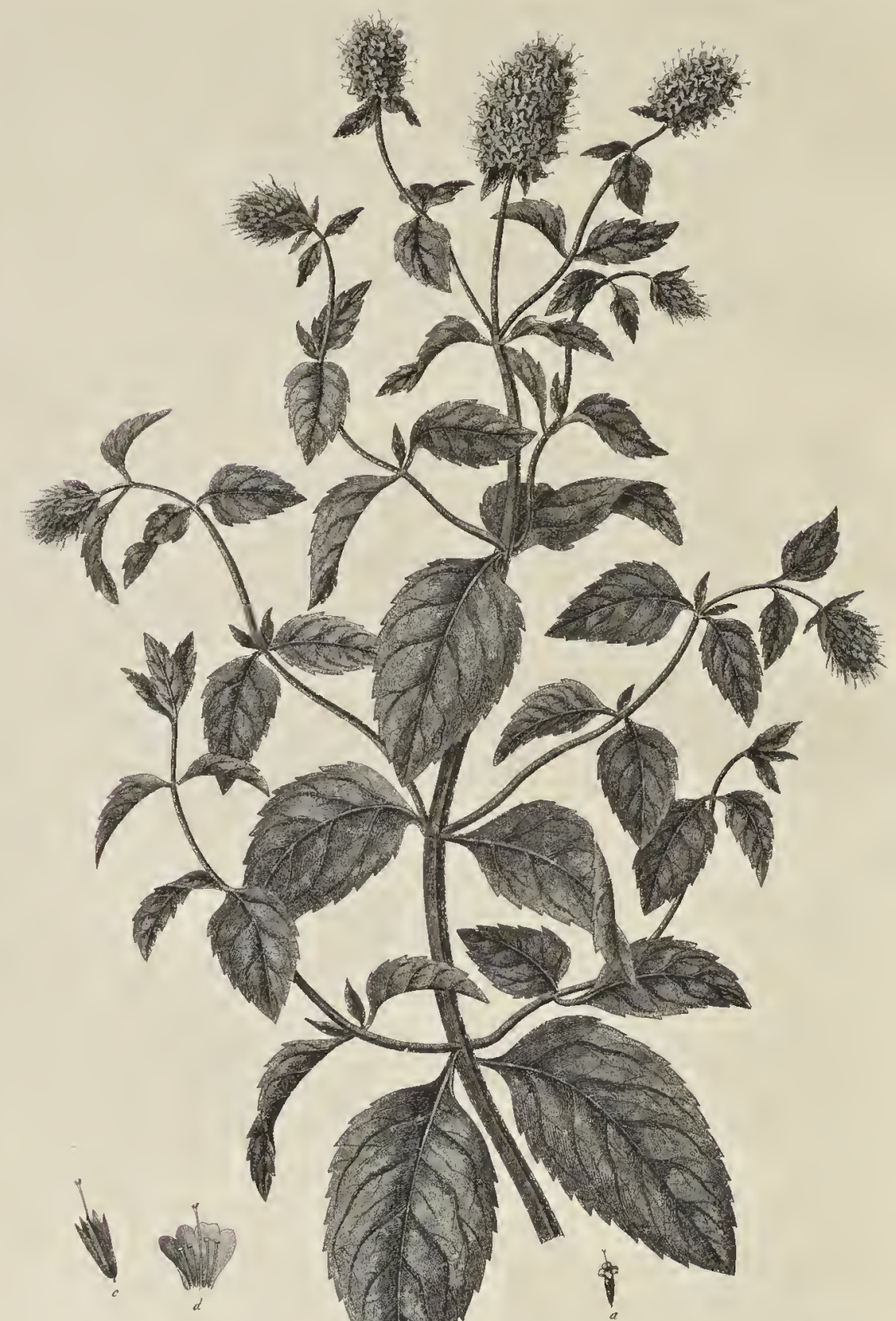

M: Piperita Vulgaris

Commen Pepper-Mint. QPath. Wuth ty YI ? ide. 797 
8. MENTHA PIPERITA VULGARIS.

Mentha fpicis capitatis, foliis ovatis ferratis petiolatis, ftaminibus corolla brevioribus. Lin. Sp. P. p. 805 .

Mentha piperita. Hud. F. A. p. $25 \mathrm{I}$.

Mentha fpicis brevioribus et habitioribus, foliis Menthæ fufcæ, fapore fervido piperis. Ray. Syn.p. 234.

Mentha piperata obtufa. Pet. H. Br.tab. xiii. fig. I I.

Hill. B. H. p. 353 .

Warner. Pl. Woodf. $p \cdot 9^{8}$.

In aquofis et fcrobibus bumentibus reperitur.

Septembri foret. 
The stalk of this plant is fquare, wreathed, or bending; it is of a reddinbrown colour, a little hairy, much branched, and grows two feet and a lialf in height; the branches, as well as the main ftalk, terminate in oblong, and very often, round heads of flowers, which are of a beautiful purplifh-red colour: the collateral branches bending and wreathing in perfect unifon with the main ftalk, give the plant a very animated and graceful mein, exhibiting at firft glance a total contraft to the foregoing. The leaves ftand on flort foot-ftalks; they are ovate, ferrated, and flightly hairy; the ftamens are fhorter than the blofioms; the calix is fprinkled with the fame fort of fpangles as that of the foregoing, but the leaves are not fo loaded with them as the leaves of the former. The whole plant has a very agreeable fmell and flavour of pepper and mint, but is not fo piquant as the foregoing; it neverthelefs make a very pleafant peppermint water when diffilled green; but the former is the right plant for drying for the ufe of the hops.

I have found it fpontaneous in various watery places about Bath, and between Wells and Glaftonbury, alfo in Chittern-bottom, Wilts.

It does not blow until the middle of September in general.

MIr. Ray's Artist, who perhaps lived at a distance, and after drawing the first lines of this plant, I suppose took it home with him to finish by memory at leisure, (rohich is too often the case) by which means he has made a centaur of it, having placed the head of common water-mint on the shoulder's of the spited pepper-nint; the leaves of which are done to admiration, and consequently in MI. Ray's presence, who, it is universally hown, was excedingly accurate.

Bamellier's Artist has commithed the same blunder of putting styles for stamens, and vice versa, $\mathbf{S i}$. for which reason that neat collection of Spanish and Italian plants is rentdered of no zalue now. Indeed there is this to be said for both, thut the sexual system was not known at that time, of course the drawing-masters were not so allentive to the number of stamens and styles as the present systen requires. 


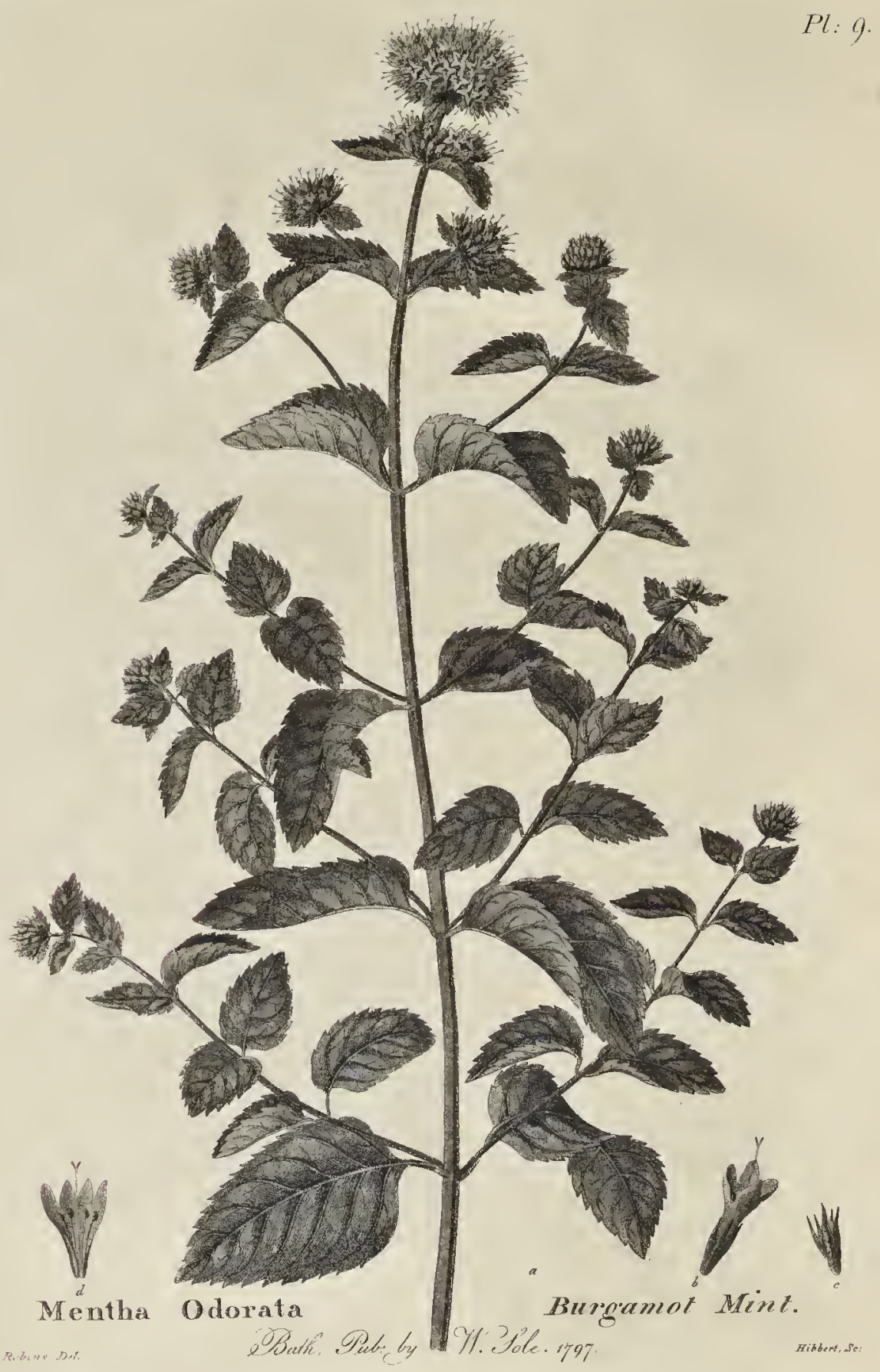


9. MENTHA ODOR.AT.A.

Mentha floribus capitatis, foliis ovatis ferratis glabrioribus petiolatis, nervis ramofis rubris, caule rubro glabriore, ftaminibus corolla brevioribus; odore gratiffimo.

Mentha balfamita vel latifolia odorata, diutiffime durat odor ejus fuaviffmus. Mer. Pin. p. 77.?

Mentha fifymbrium dicta hirfuta, glomerulis ac foliis minoribus ac rotundioribus, odor valde gratus et aromaticus mala aurantia plane xmulans. R. Syn. p. 233.tab. x. fig. 1.

Mentha odorata flore cinericeo. R. Syn. Pl. dub.

Mentha rotundifolia fpicata altera. Mor. H. O. Ject. xi. $t a b$. vi. fig. 3 .

Mentha aquatica hirfuta foliis minoribus. Hill. B. H. p. 352 .

Mentha aquatica, $\gamma$. Hud. F. A. p. 252 .

Habitat in paludibus et aquofis, fed rarius.

Sub finem Fulii floret. 


\section{BERGAMOT MINT.}

THE ftalk of this Mint is quadrangular, almoft fmooth, of a mahogany colour, much branched, and grows about two feet high, terminating in a large round head of flowers, and two collateral heads at the joint below it; the collateral branches alfo all terminate in a head of flowers, which are of a light red colour; the leaves ftand on fhort footitalks, they are concave, ovate, and ferrated; the nerves and very often the under fides of the leaves are red; the ftamens arc fhorter than the bloffoms: the whole plant has a mort agreeable fmell of Bergamot. The heads are not ftrictly globular, but are a little depreffed at the tops: this hint correfponds in every thing to Linnæus's aquatica, but in the ftamens being fhorter than the bloffom. The late Mrs. Walmfley, of Bath, when I hewed her this Mint as a curiofity in the year 1772 , informed me that it was very common by riverfides and brooks in Chefhire, particularly in the neighbourhood of her father's houfe, (Afton-houfe) and that it was well known there by the name of Water-Mint. I found my plant in a fmall brook or ditch near Capel-Carey, between Llandrooft and Llanberrys, North-Wales.

Morrifon has thrown great light on this plant by giving us two figures of it, one fmooth like his and mine, and one hairy like Ray's: it is well known that the difference of foil conftitutes this difference. Both Morrifon and Ray's figures exhibit the ftamens longer than the bloffoms; but as neither of them mention any thing of this, I am inclined to think it is owing to an error of the artift, who has drawn ftamens for ftyles, as in Ray's pepper-mint; and this appears ftill more likely to be the cafe, as in looking wifly into them we find but one ftamen in each bloffom, which ought to contain four, with a fingle bifid ftyle in the midft of them, of which there is no appearance. 



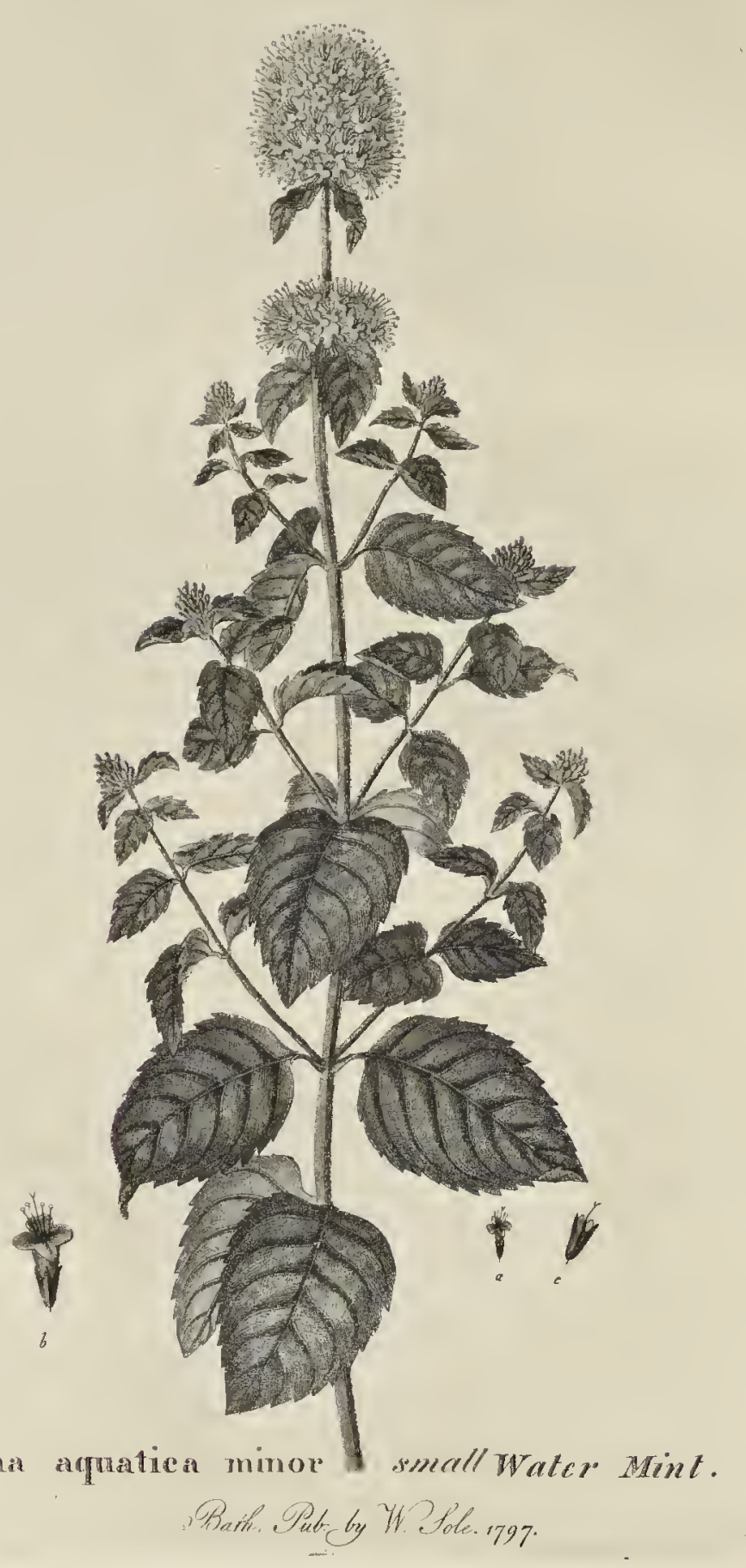

Pl:/l. 
Io. MENTHA AQUATICA MINOR.

Mentha floribus capitatis, foliis ovatis ferratis fubfeffilibus pubefcentibus ftaminibus corolla longioribus. Lin. Sy/t. Nat. p. 392, No. xv. Mentha aquatica, five Sifymbrium hirfutius. F. B. Hiff. iii. $p$. 224. ico. Mor. H.O. iii. p. 370.

Mentha rotundifolia paluftris minor five flore globofo. C. B. Pin. p. 228 . Sifymbrium hirfutum. R. Syn. p. 233 .

Mentha aquatica folio brevi hirfuto. Hill. B. H. p. $35^{2}$.

Mentha aquatica, f. Hud. F. A. p. 252.

Salis fuccini odore.

Habitat in locis uliginofis et aquofis.

Sub finem Fulii foret. 
THIS plant grows about a foot and a half in height; its ftalk is fquare, upright, hairy, and much branched, terminating in a fuperb round head of flowers, with two collateral ones at the joint immediately under it; the collateral branches alfo terminate in a head of flowers, but they are fmaller than thofe of the main ftalk; the flowers are of a beautiful vivid red colour, with the ftamens longer than the bloffom. The leaves are rigid, a little crifped or curled, the lower ones ftanding on fhort foot-ftalks, but the upper ones are feflile; they are of a dark green above and almoft fmooth, but pale and hairy underneath; their thape is partly ovate and partly cordate; they are ferrated and thort-pointed, and their nerves are particularly ftrong and harh.

This plant, when in bloom, is of fingular beauty, and worthy of admiration: it has a ftrong volatile fmell of falt of amber, and of courfe is an excellent antihyfterick and cephalick.

I have rejected the term birfuta, becaufe in Somerfethire, Wilthire, and in Wales, it is a great deal fmoother than the aquatica major, althougl in Hornfey-lane near London, and fome other fituations, I have obferved it to be more hairy, but it is by no means conftantly fo.

It grows frequently in fwamps in elevated fituations, fucl as the fides of our downs, Mendip-liills, \&c.

It flowers towards the end of July. 



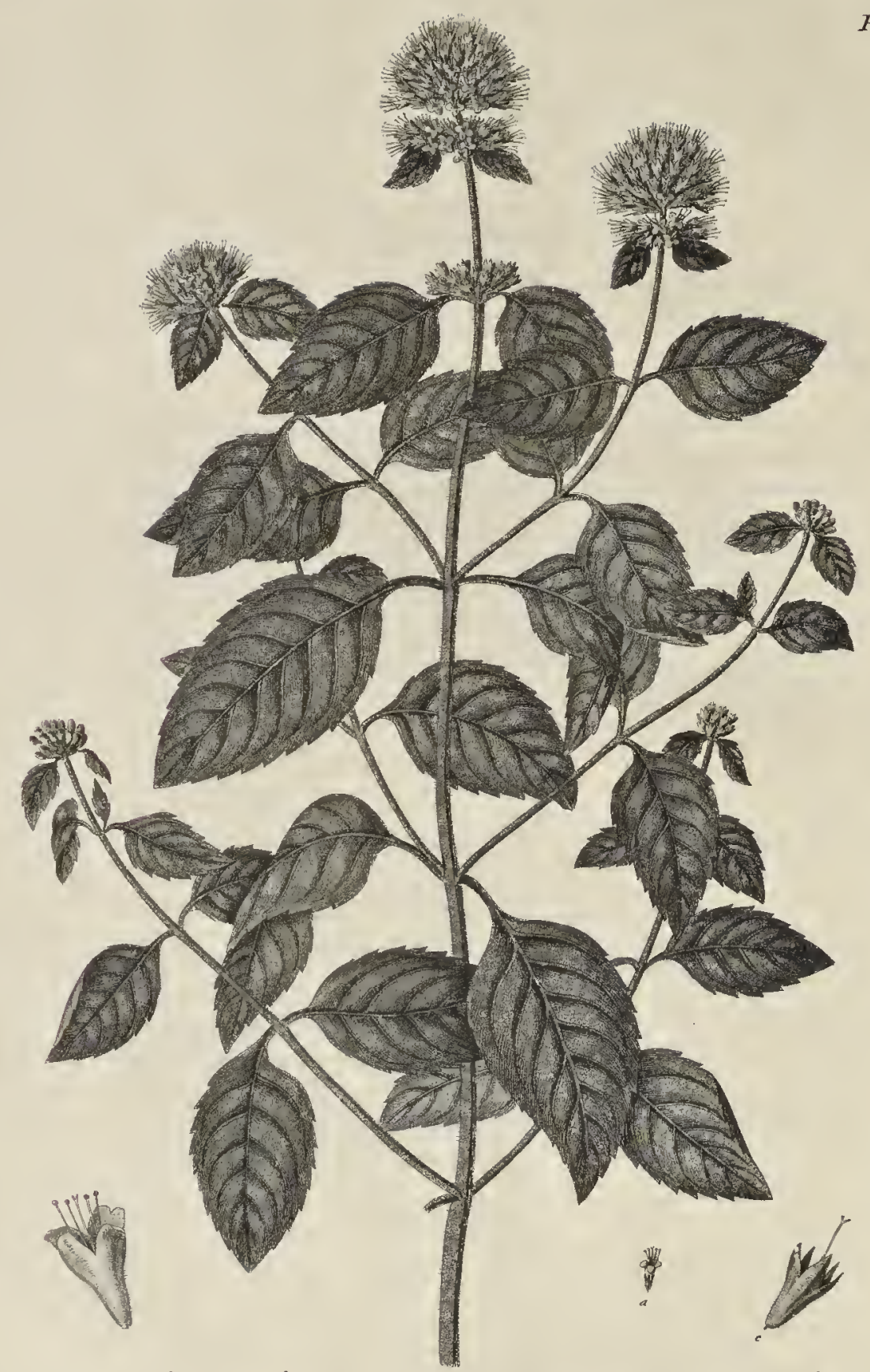

M: Aquatica inidor

precet Winter Mint.

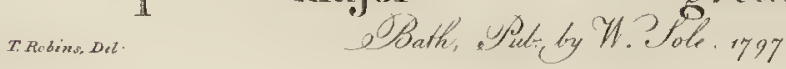


II. MENTHA AQUATICA MAJOR.

Mentha floribus capitatis, foliis ovatis ferratis petiolatis, ftaminibus corolla longioribus. Lin. Flo. Suec.'ed. 2. p. 202.

Mentha aquatica. Hud. F. A.p. 252.

Sifymbrium fylveftre. Matb. $p \cdot 37^{8}$, ico.

Mentha aquatica, five Sifymbrium. F. B. H. iii. p. 223. ico.

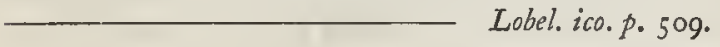

Ger.em. p. 684. ico. Lob.

R. Syn. p. 233.

Blackwell. H. t. 32 .

Lewis. Mat. Med.

Mentha rotundifolia paluftris, feu aquatica major. C. B. Pin.p. 227 .

Mor. H.O. §. xi. tab. 7.f. 6.

Map. Al.p. 193 .

Threlkeld. Syn. Hibern.

Mentha aquatica rubra. Park. $p .1243$.

Mentha aquatica folio brevi lato. Hill. B. H. p. $35^{2}$.

Mentha foliis ovato-lanceolatis ferratis, verticillis pauciffimis terminante maximo. Hal. No. ccxxv.

Mentha viii. Tourn. Inft.

Odore fuliginofo.

Habitat in aquofis et ad rivulos.

Augufto floret.

Foliis aliquando majoribus, aliquando miroribus, aliquando tota rubens, aliquando mag is minusque hirsutis. J. B.

Odor palidosus, acris planta, aromatica, amara est.Haller. 
THIS plant grows from three to five feet in height; its ftalk is fquare, deeply furrowed or fulcated, green, hairy, and terminates in one great oblong head of flowers, below which there are ufually two clufters of flowers, and often a third fet ftanding on footftalks, iffuing from the bofoms of the leaves; they are of a light purple colour, divided into four fegments; the upper fegment, as in all the mints, being bifid or cleft, but in this moft eminently fo; the ftamens are taller than the bloffom; the leaves ftand on longin footftalks, and are (as in all its congeners the Sifymbria) round and red underneath until the latter end of May, when they begin to affume their proper fhape, and by degrees become pointed, green, hairy, broad, ovate, elliptical, and oblong; for nature fports much in the labit of this plant according to the variety of foils and fituations; for inftance, in the brooks at Twiford, it is five feet high, with broad elliptical leaves almoft fmooth; in our ditches and rivulets about Bath it is exceedingly hairy, with ovate leaves, and does not exceed three feet in height; on our downs again it is procumbent, hoary, and its leaves acuminated; but its peculiar fmell points out the plant in all its various fituations, which is exactly that of a ropy chimney in a wet fummer, where wood fires have been kept in winter-time. Tea made of its green leaves is excellent in all nervous and hyfterick cafes, and wherever woodfoot and Ruffia caftor are ufeful, the tea of this plant is not only a fine auxiliary, but in cafes of need an excellent fubftitute: I fpeak this from my own experience.

Our anceftors, from long before the time of Dr. Turner to the middle of this prefent century, held it defervedly in high eftimation as a nervous medicine, and made great ufe of it.

Toumefort, in his excellent Inftitutes, obferves, that there is a volatile oily falt in this plant, which is very aromatick, ftomachick, and diuretick, and that the leaves give out their virtue being made into tea.

It is a very common plant growing in watery places all over England. It flowers in Auguit. 



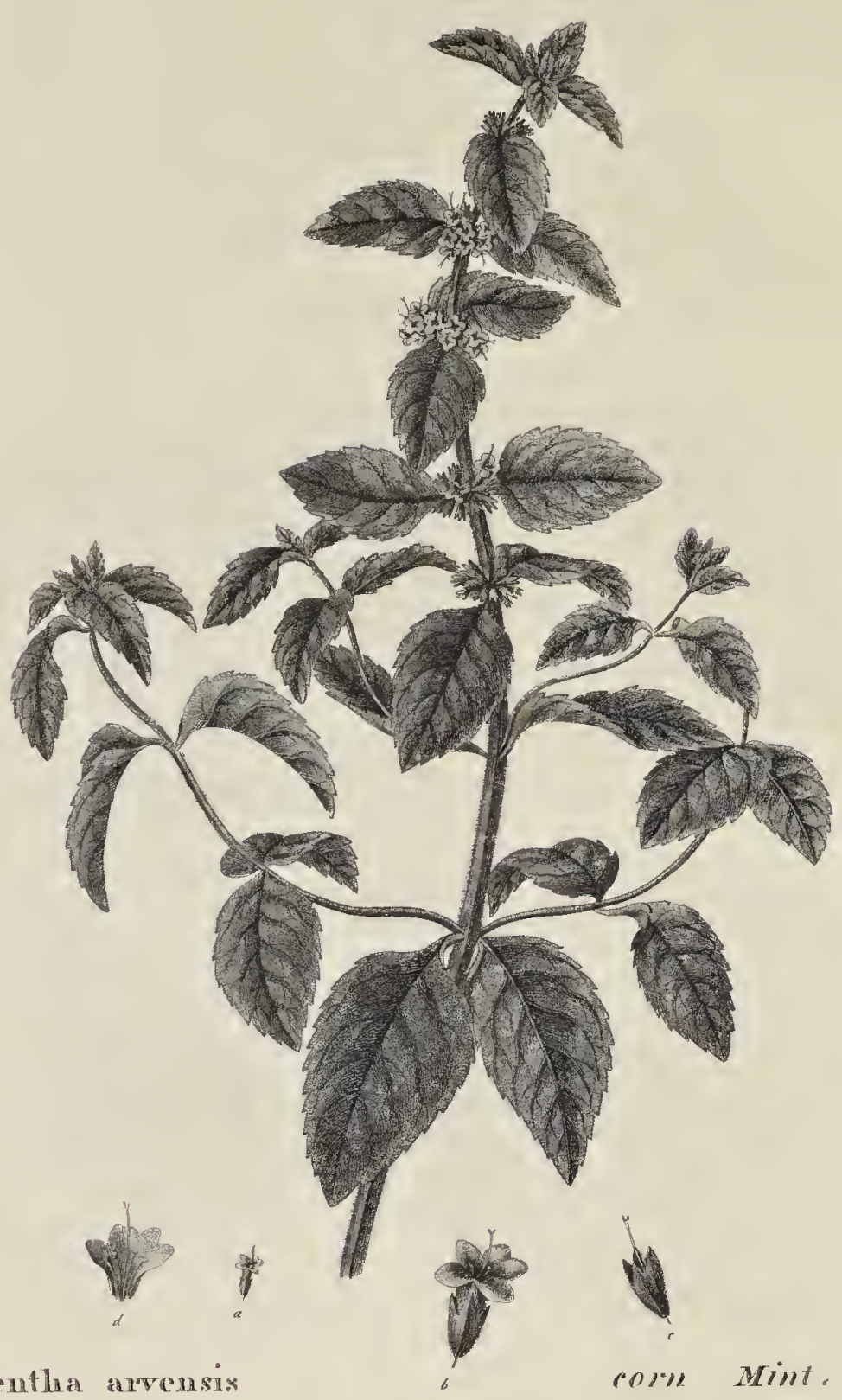

Montha arvensis

$$
\text { QDath. Mutbi by WI ? Pote } 797
$$




\title{
MENTHE BRITANNICE.
}

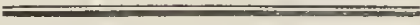 \\ SERIES TERTIA. \\ MENTHÆ VERTICILLATAE.
}
12. Mentha arvenfis.
I3. - præcox.
14. — agrentis.
15. - gentilis.
16. -
I7. - pratenfis.
18. rubra.
Ig. — variegata.
20. rivalis.
21. - - fativa.
22. — paludofa.
23. — Pulegium. 


\section{BRITISH MINTS.}

SERIES THE THIRD.

WHIRLED MINTS.

Confifting of fuch Mints as produce their flowers in whirls round the ftalks in the bofom of the leaves, and contains the eleven following Mints:

12. Corn Mint.

13. Early-flowering Mint.

14. Field Mint.

15. Cardiac Mint.

16. Slender Mint.

17. Meadow Mint.

18. Common red Mint.

19. Variegated or Window Mint.

20. Brook Mint.

21. Tall red Mint, or old Garden Mint.

22. Fen Mint.

23. Penny-Royal. 
Mentha floribus verticillatis, foliis ovatis acutis ferratis, ftaminibus corollam xquantibus. Lin. $S p \cdot p .806$.

Calamintha aquatica. Math. p. 529. ico. nitid.

Mentha arvenfis verticillata hirfuta. $\mathcal{F} . B . H$. iii. $p .217 . i c 0$.

$$
\text { Map. Al.p. } 193 .
$$

Calamintha arvenfis verticillata. C.B.Pin. p. 229.

Park. p. 36. ico. Lob.

Calamintha aquatica Belgarum et Math. Lob. icon. p. 505 .

$$
\text { Ger. em. p. 684. ico. Lob. }
$$

Mentha feu Calamintha aquatica. $R$. Syn. $p \cdot 232$. No. i.

Mentha aquatica exigua. $R . S y n . p \cdot 232$. No. ii.

Mentha No. x. Tourn. Inft.

Mentha arvenfis verticillata procumbens.

$$
\text { Mor. H. O. iii. p. } 369 \cdot \text { fect. xi. tab. 7. fig. } 5 \text {. }
$$

Mentha aquatica hirfuta verticillata, Hill. B. H.p. 35 r. ico. Lob.

Mentha floribus verticillatis hirfutis, foliis ovato-lanceolatis, verticillis tomentofis, odore mihi deteftabili fubdulci. Hal. Helv. No. ccxxiii.

Mentha foribus verticillatis, caulibus diffufis, foliis petiolatis ovatis ferratis villofis. Hud. F. A. p. 253 .

$\beta$. Mentha arvenfis erecta anguftifolia, caule rubefcente, odore grato.

Calaminta aquatica. Blackroell. H. tab. I 31 .

$\gamma$. Mentha arvenfis major, veticillis et floribus amplis, foliis latioribus, ftaminibus corolla longioribus odore grato.

\section{Habitat in arvis.}

B. -.. in aquofis arenofis.

\%. - in pratis bumidis.

Fulio florent. 
THIS Mint does not much exceed one foot in height; its ftalk is fquare, pale, very hairy, and quite overloaded with horizontal branches, which weigh it down and prevent its being upright; the leaves ftand on thort footftalks; they are hairy, ovate, ferrated, and of a pale-green colour.

The whirls ftand at the joints in the bofoms of the leaves, and clofely embrace the ftalk all round; the flowers are of a pleafant red colour; the ftamens generally fhorter than the bloffom; the calix or cup is quite woolly.

This plant has a ftrong fullfome mixed fmell of mellow apples and gingerbread, by which it may be always known in all fituations. Some authors have puzzled themfelves and their readers by making J. Bauhin's figure of arvenfis, a diftinct plant from Lobel's belgarum, which are certainly figures of the fame plant in different fituations; witnefs C. B. who quotes both of them to his arvenfis, as does Morrifon alfo.

In gravelly and fandy foils, as Hounflow-heath, Epping, and Windfor forelts, this plant is not above fix or feven inches high, whence fome have termed it exigua, but its peculiar fmell will always detect it. It is common in corn-fields and thallow waters, and flowers at the latter end of of July and in Augut.

There are two diffinet varieties of this plant.

1. Corn Mint with an upright ftalk, red, not much branched, growing to the height of two feet, with long, narrow, and almoft fmooth leaves, and an agreeable fmell. Mrs. Blackwell has drawn this variety for her Corn Mint. It grows in hallow waters on fandy heaths.

2. Great Corn Mint with broad, ovate, deep-green leaves; ftalk hairy, much branched, and two feet high, and not unpleafant in its fmell; the ftamens longer than the bloffom. It grows in moift meadows frequently. 



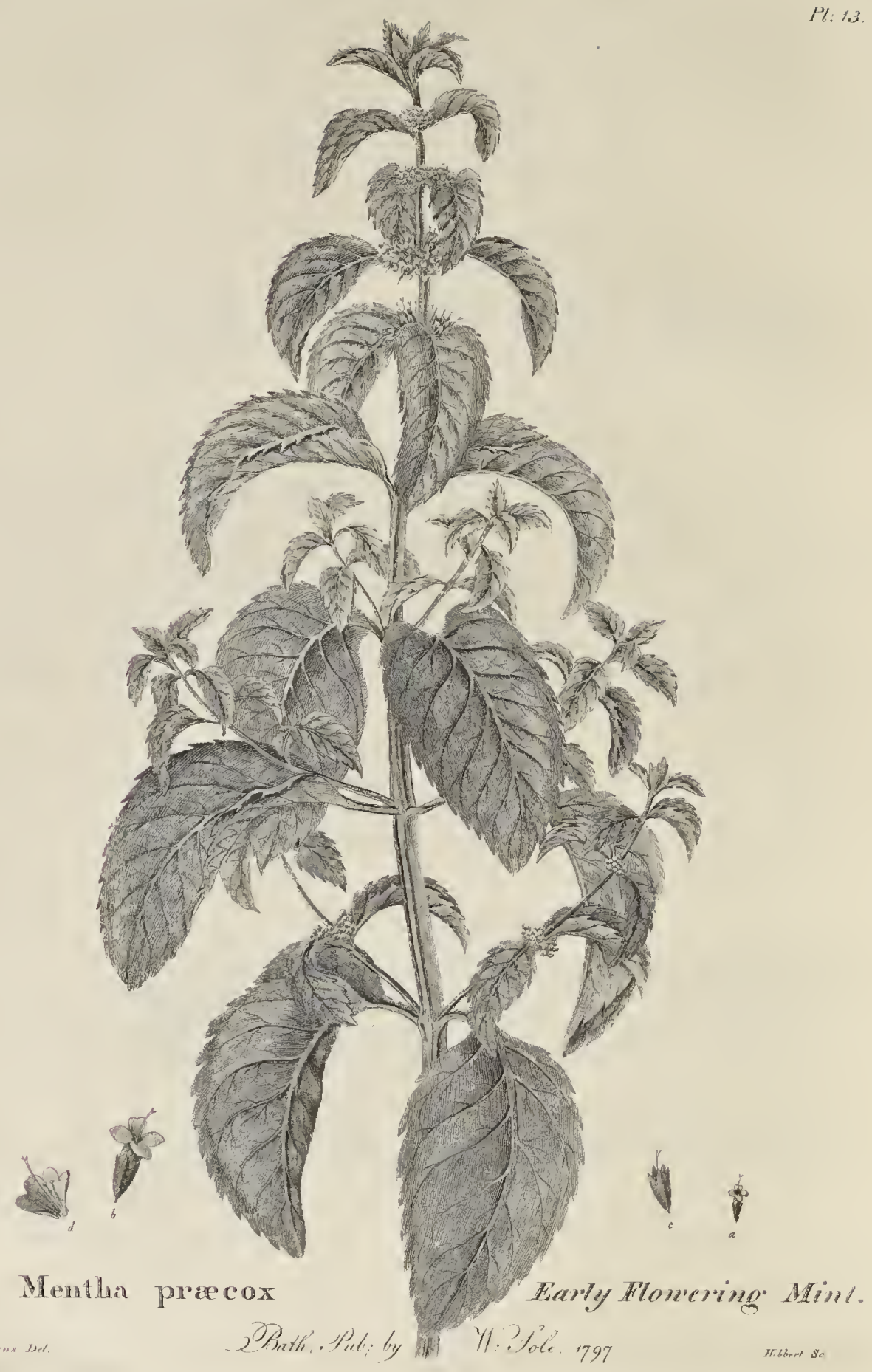


TAB. xiii.

3. MENTHA PRECOX. '

Mentha floribus virticillatis, caule erecto fubnudo albido, ramis brevioribus erectis, foliis elliptico-lanceolatis petiolatis ferratis glabrioribus, nervis albis, ftaminibus corolla brevioribus: Calami aromatici odore. Mentha auftriaca, Jacquin?

Habitat ad ripas furviorum.

Funiö foret. 
The ftalk of this Mint is upright, of a pale whitifh colour, almoft fmooth, and not much branched; the branches are fhort, upright, and diftant; the joints between the leaves being much longer in this Mint than in many others; the leaves ftand on fhort white footftalks; they are oblong, fmooth, ferrated, and pointed, the nerves of which are white and fimple; the whirls ftand in the bofoms of the leaves towards the top of the ftalk; the flowers are of a bright pink colour, with ftamens thorter than the bloffom; the fmell of this plant is much like that of the fweet flag.

This Mint has very much the face and habit of Jacquin's auftriaca, but is much larger, which may proceed from fituation.

It grows by the fide of the river Avon near Bath, in various places, and blows in the middle of June, which is at leaft a fortnight or three weeks fooner than any other. 



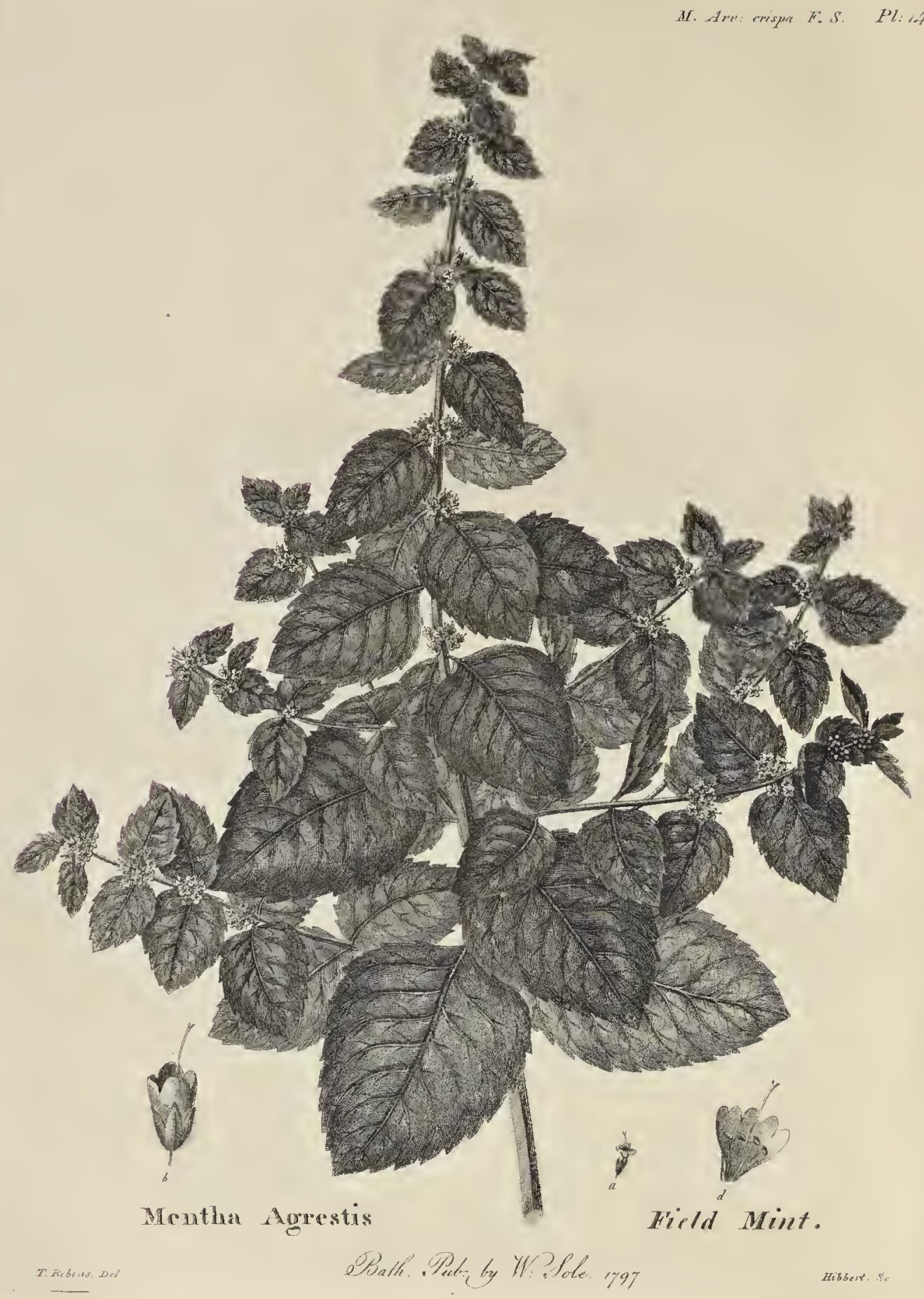


14. MENTHA AGRESTIS.

Mentha floribus verticillatis, caule erecto hirfuto ramofo; foliis petiolatis crifpis rugofis ferratis villofis fubrotundis; ftaminibus corolla brevioribus; odore aromatico.

Mentha arvenfis verticillata folio rotundiore odore aromatico. R. Syn. 232. Mentha xi. Tourn. Inft.

Mentha aromatica folio rotundiore. Hill. B. H. $p .351$.

Mentha arvenfis, B. Hud. F. A.p. 253.

Habitat in arvis et bortis incultis frequenter.

Fulio froret. 
THE ftalk of this Mint is fquare, upright, hairy, and much branched; the leaves ftand on very fhort footftalks; they are broad, wrinkled, hairy, ferrated, almoft round, and of a dark-green colour; the clufters of flowers ftand in the bofoms of the leaves furrounding the ftalk, and are of a bright-red colour; the ftamens are fhorter than the bloffom; the cups of the flowers are hairy, not woolly as in Corn Mint: it has a pleafant aromatick fmell.

This Mint grows in com-fields about Mendip hills, Shepton-Mallet, and Frome, and in neglected gardens in that part of Somerfethire abundantly; and as the Corn Mint is found in the fame fields and gardens in common with it, they certainly cannot be the fame as fome authors contend.

It blows towards the end of July. 


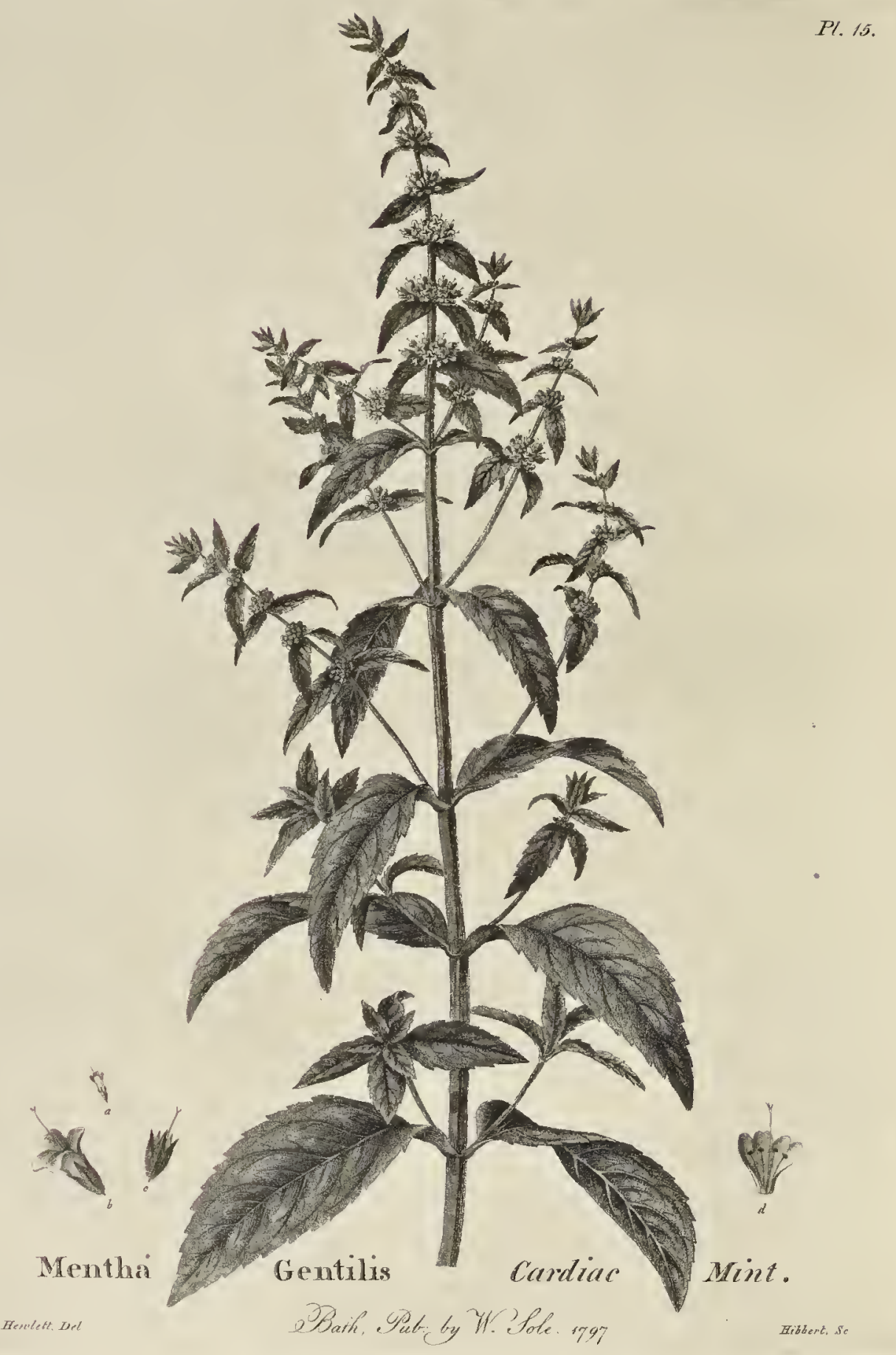


I5. MENTHA GENTILIS.

Mentha floribus verticillatis, bracteis longis acuminatis feffillibus, caule erecto ramofo fufco;foliis 3 oblongo-lanceolatis fubpetiolatis ferratis glabrioribus, nervis fufcis, ftaminibus corolla brevioribus; ocymi odore.

Mentha floribus verticillatis, foliis ovatis acutis ferratis, ftaminibus corolla brevioribus. Lin. Sp.P.p. 805 .

Mentha hortenfis iv. Fufch.

Mentha verticillata, minor, acuta, non crifpa odore ocimi. F. B. H. iii, $p .217$.

Mentha hortenfis verticillata ocimi odore. C. B. Pin. p. 227 . Mor. H. O. fect. xi. tab. 7.f. 1.

Romana anguftifolia five Mentha cardiaca. Lob. ico.p. 508 .

Mentha cardiaca. Ger. em. p. 680. Park. p. $3 \mathrm{I}$.

Mentha iii. Tourn, Inft.

Mentha gentilis. Hud. F. A. p. 252 .

Habitat in pratis bumidis, fed rarius; in fimetis et ruderatis frequentèr.

Fulio floret. 
15. CARDIAC MINT.

CARDIAC Mint grows about two feet in height; its ftalk is upright, branched, of a dark-brown colour and almort fmooth; the leaves are fmooth, long, narrow, ferrated, and acuminated, of a deep green colour; the lower leaves ftand on thort footitalks, but the upper ones are feffile; the clufters of flowers grow in the bofoms of the leaves towards the top of the ftalks and branches; they are very numerous, and the floral leaves being very long and narrow, give it fo much the habit of Spear-Mint, that it is often taken for it-and Parkinfon himfelf calls it Spear-Mint, being in his time conftantly ufed for it ; and our cottagers in SomerfetShire and Wilthire ftill retain it in their gardens for the true Spear-Mint, but is very inferior to it as a febrifuge; although as a ftomachick and cardiack, I believe it excels it.

The flowers are of a pale pink colour, and the ftamens fhorter than the bloffom.

This plant is very frequent in ditches, and wafte places near towns and villages; but a true fpontaneous babitat I have never had the good luck to ftumble on.

It blooms in Augurt. 



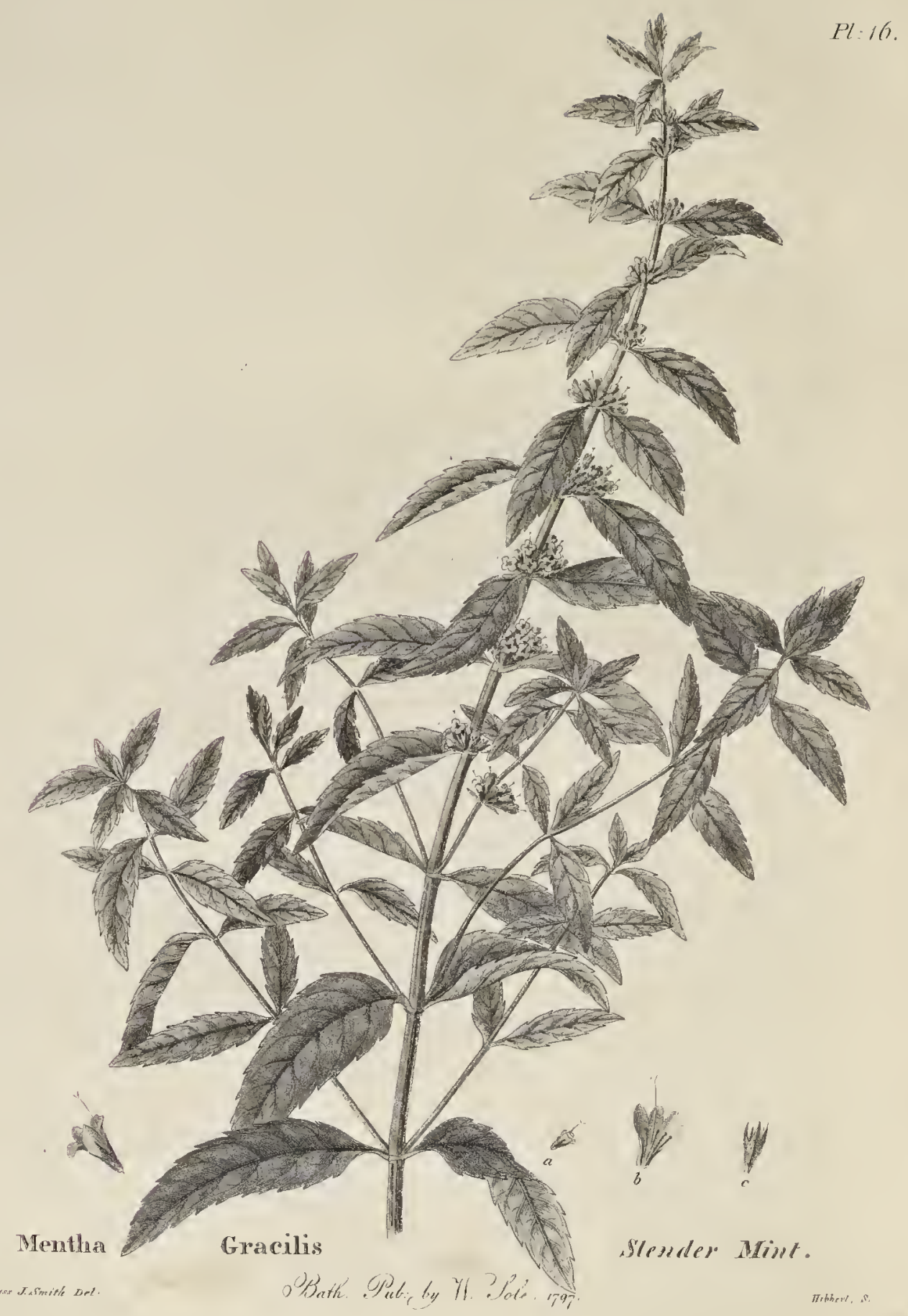


16. MENTHA GR.ACILIS.

Mentha floribus verticillatis, verticillis paucioribus ac minoribus, foliis petiolatis ovato-lanceolatis ferratis, fubhirfutis, nervis albis pilofis, caulc erecto pilofo fuffruticofo exalbido rubefcente fubramofo, ramulis brevibus erectis, ftaminibus corolla brevioribus; odore grato.

Mentha rubra vulgaris. Hill. B. H. p. $35^{2}$.

Habitat in aquofis et ad ripas furviorum.

Augufto floret. 
THIS Mint grows to the height of two feet and more; the ftalks are flender, hard, and upright, very little branched, with very fmall, upright branches, which feldom afford any bloffoms; they are at firft white, and, by degrees, become of a pale-brown colour; the whirls of flowers are fewer and fmaller than in the preceding; the leaves ftand on footftalks, are of a long ovate pointed fhape, a little hairy and ferrated; the nerves are white: it has an agreeable aromatic-minty fmell. The ftamens are fhorter than the bloffoms.

It differs from the foregoing in having no fmell of Bafil, and the floral leaves are broader and ftand on footftalks, whereas in the former they are feffile and very narrow, merely bracteals; nor has it the leaft refemblance of fpear-mint, which that has. Moreover, a perion laying out a fpecimen of gentilis for drying will not be able to wafh off the Bafil fmell from his hands in hafte; on the contrary, this plant leaves a pleafant fmell, and is eafily wafhed off.

It grows by the fides of rivers and brooks, but very fparingly. I found this by the fide of a brook near Bradford, Wilts, in the year $177^{2}$. 


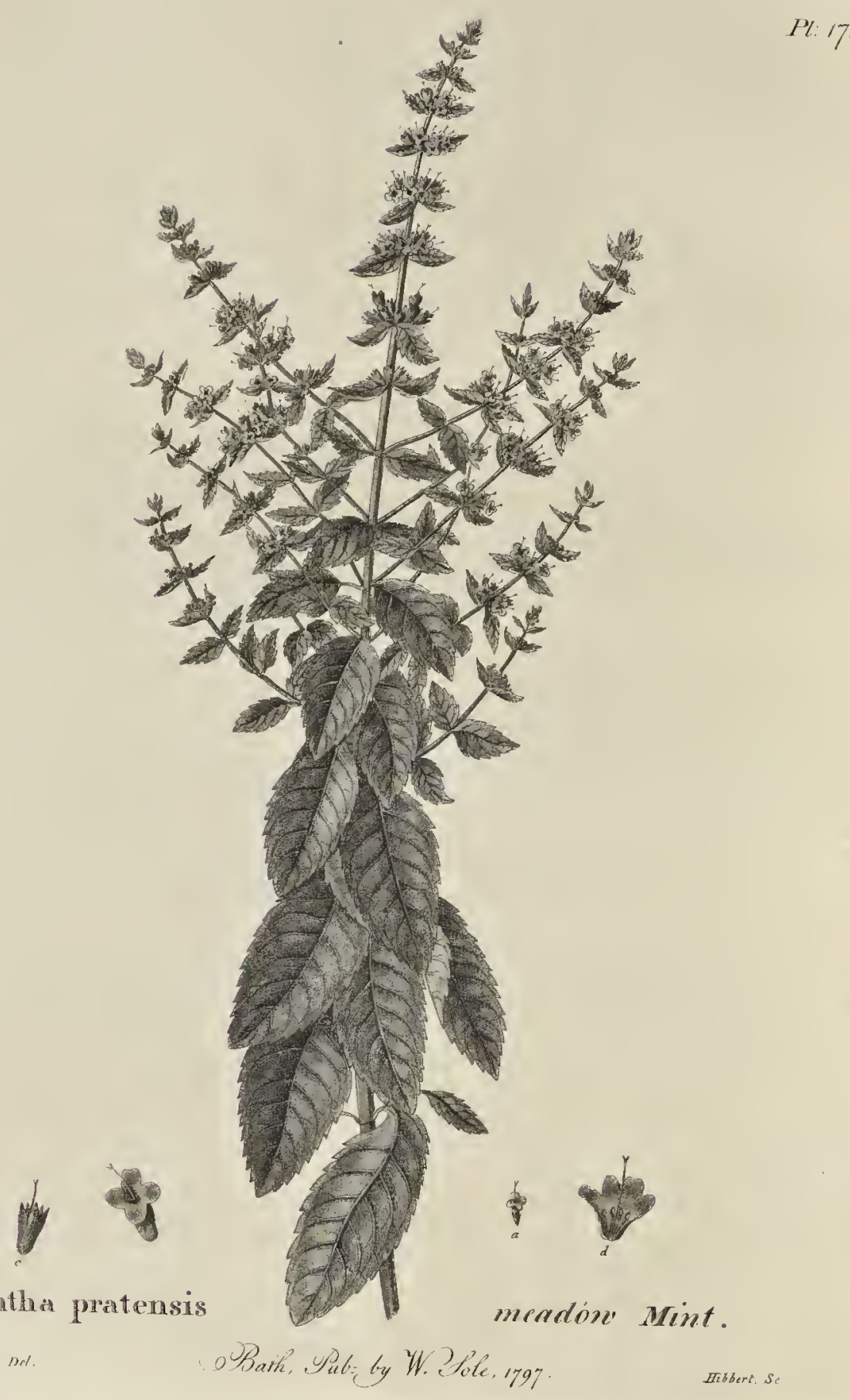


I7. MENTHA PRATENSIS.

Mentha floribus verticillatis, foliis ovalibus obtufis argute-ferratis fubpetiolatis rugofis rigidis hirfutis, foliis caulinis dependentibus; caule hirfuto erecto, fuperne ramofo, inferne fimplice, ex pallido-viride fufcefcente; verticillis habituoribus ac minoribus, floribus purpurocœruleis, ftaminibus corolla brevioribus; Menthæ piperitæ odore.

Habitat in uliginofis montofis.

Sub finem Augufi floret. 
THIS Mint grows from two to three feet in height; its ftalk is upright, and branched only towards the top, turning by degrees from pale-green to a dark-brown colour; thefe branches as well as the main ftalk, are full of whirls of flowers, very much refembling thofe of penny-royal. The leaves are oval; they have hort footftalks, are harfh, wrinkled, hairy, and deeply ferrated; and what is very peculiar to this mint, the leaves all the way up the ftalk to where the branches commence are depending, and hang down clofe to the ftalk; the ftamens are fhorter than the bloffom: it has a ftrong fmell of pepper-mint, and might, with propriety, be called Whirled Pepper-Mint.

\section{It blooms in Auguft.}

I found this plant in the year 1789 , in wet places in the New Foreft, Hants, particularly in a common, (Alderbury common) near the Roebuck, between Salifbury and Romfey. It has not varied in the leaft by cultivation. 


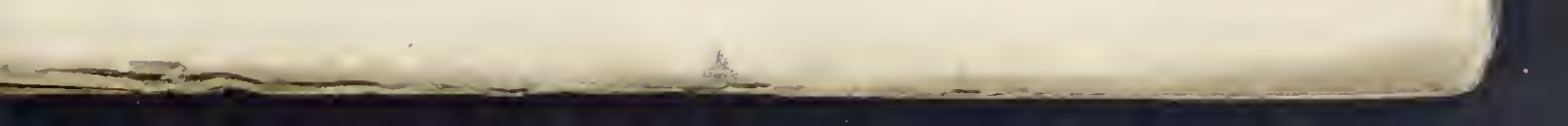


H/: 18

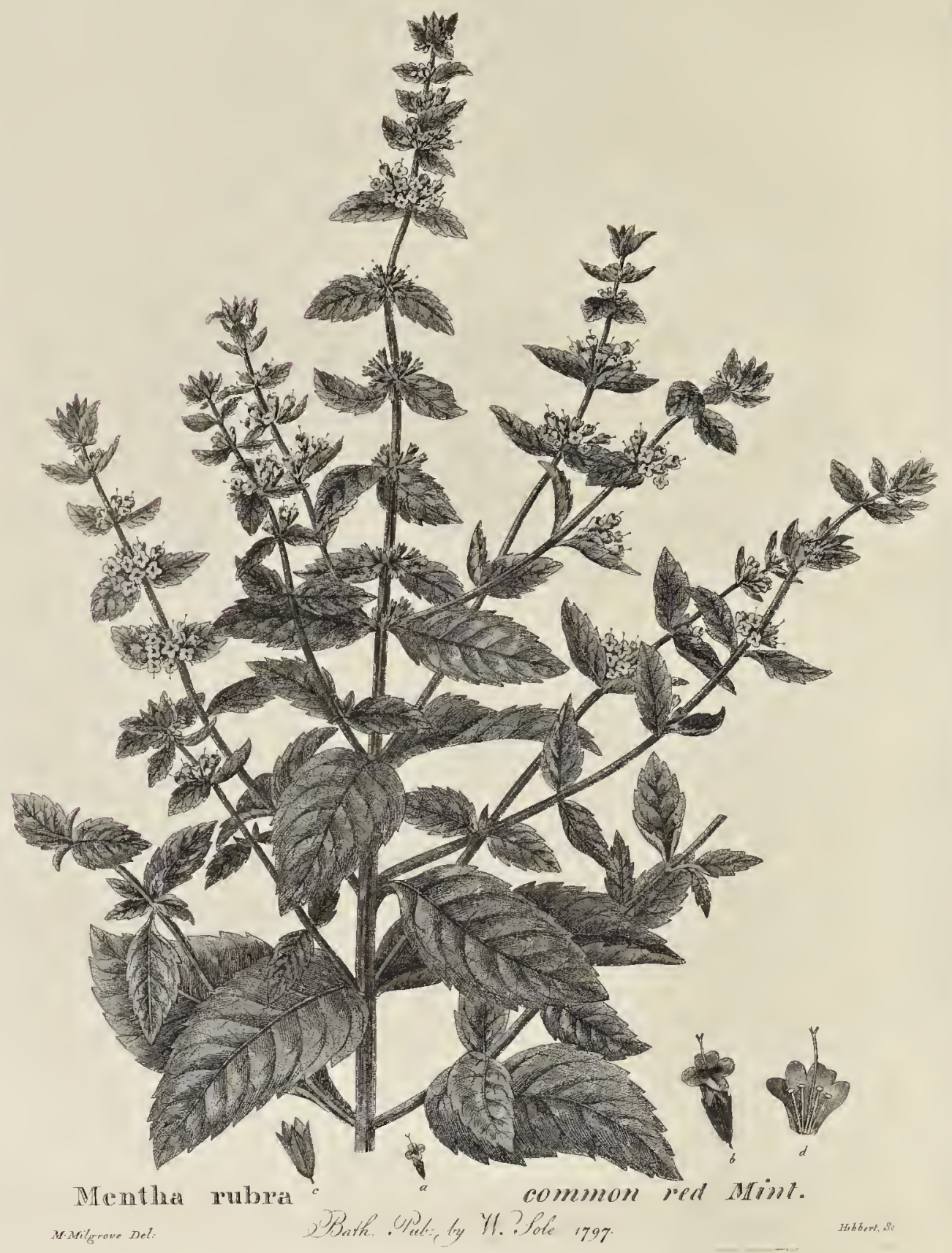


I8. MENTHA RUBRA.

Mentha floribus verticillatis, caulibus herbaceis diffufis fubglabris rubris, foliis ovatis acutis ferratis petiolatis, ftaminibus corolla brevioribus; odore grato.

Mentha fufca five vulgaris. Park. p. 3 I.

Ray. Syn. p. 232.

Habitat in aquofis et ad rivulos, fed rarius.

Fulio foret. 


\section{I8. RED MINT.}

THIS Mint grows about a foot and a half in height; the ftalk is of a deep red colour, very much branched, herbaceous, and almoft fmooth; the leaves ftand on thort footftalks, they are ovate, ferrated, roundifh, and pointed; the nerves are red, which, as well as the edges, are a little hairy; the whirls are very numerous both on the main ftalk and collateral branches, and the bloffoms are large and of a red colour; the ftamens are fhorter than the bloffom: it has an agreeable aromatick minty fmell.

"This is a common mint, but has no fmell of bafil." Mr. S. Dale. R. Syn. p. 232 .

It grows fpontaneous in pools and brooks between Mole and Llanrwft, North-Wales, whence I brought it twenty years ago.

It blooms in July.

Mr. Hudfon, in his Flora Anglica, has blended this and Nos. 15 and 16 all together as one plant; but as they keep their diftinctions after twenty years cultivation, I am induced to think they are three feparate plants, and accordingly give them as fuch. 

PIV 10.

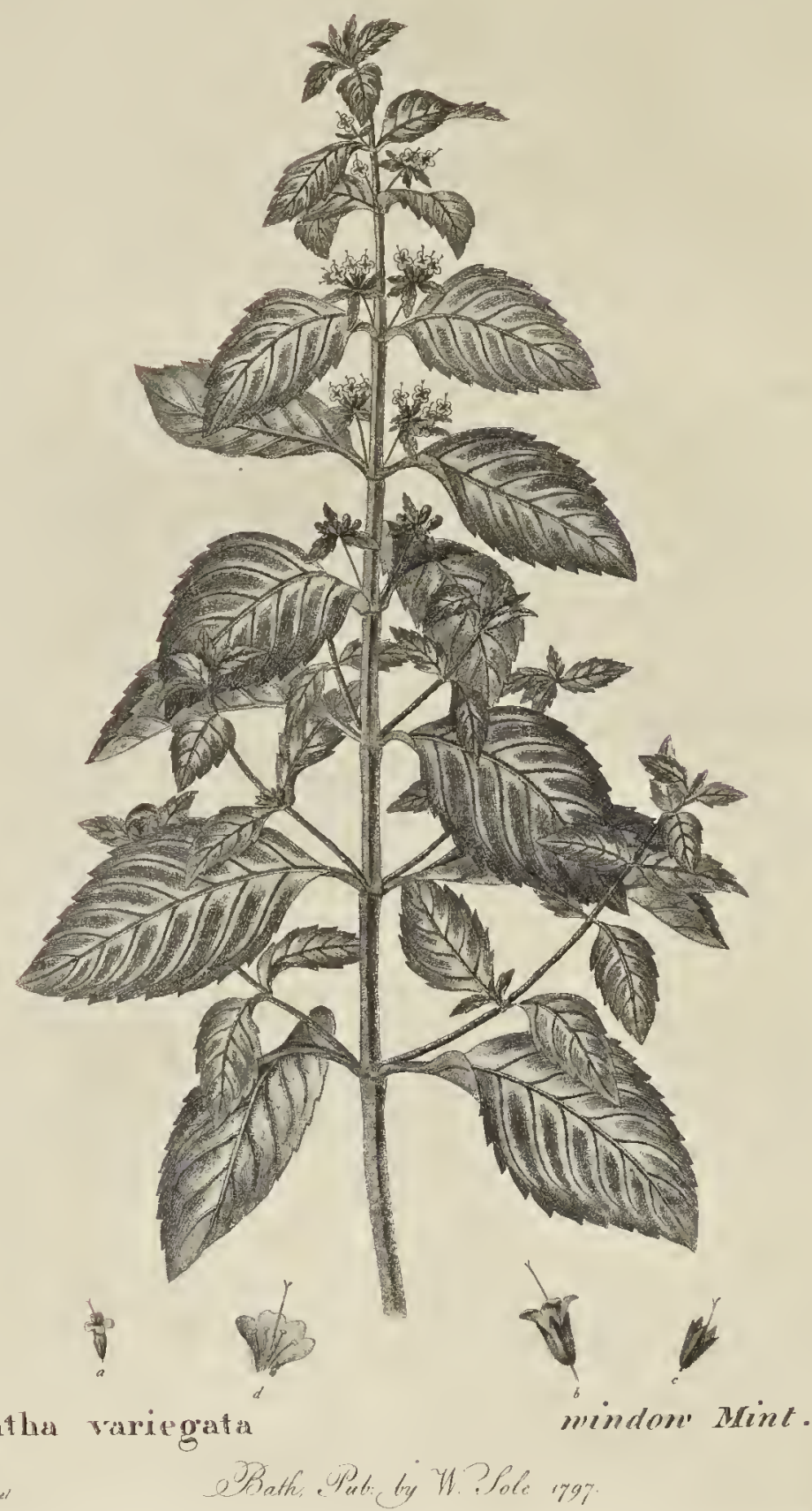


19. MENTHA V゙ARIEGATA.

Mentha verticillis lateralibus pedunculatis, foliis petiolatis ovatis acutis ferratis variegatis pubefcentibus, caule erecto rubro glabriore fubramofo, ftaminibus corolla brevioribus; odore grato.

Mentha arvenfis verticillata verficolor. Mor. H. O. fect. xi, t. $7 \cdot f \cdot 5 \cdot$ prima.

Habitat in ruderatis.

Augufto foret. 
19. WINDOW MINT.

THIS plant grows from a foot and a lalf to two feet in height; its ftalk is fquare, red, upright, and not much branched; the leaves ftand on footitalks; they are ovate, ferrated, pointed, and beautifully variegated with green and gold-coloured ftripes; the clufters of flowers are lateral, and are fupported by one common long footitalk. It is a favourite plant of our Wilthire and Somerfet cottagers, and many of them cultivate it in pots to ornament their windows, for which purpore it is admirably adapted: I have for this reafon called it Window Mint.

The clufters contain but few flowers, and they are fmall and red; the ftamens are fhorter than the bloffoms: it has an agreeable aromatick fmell, and blows in Auguit.

Morrifon, who is the only author I have met with that treats of it, gives it as a variety of corn mint; but the eye, at the very firft glance, determines it to be different.

It is often met with in fuburbs of towns, but I have never found it fpontaneous. 



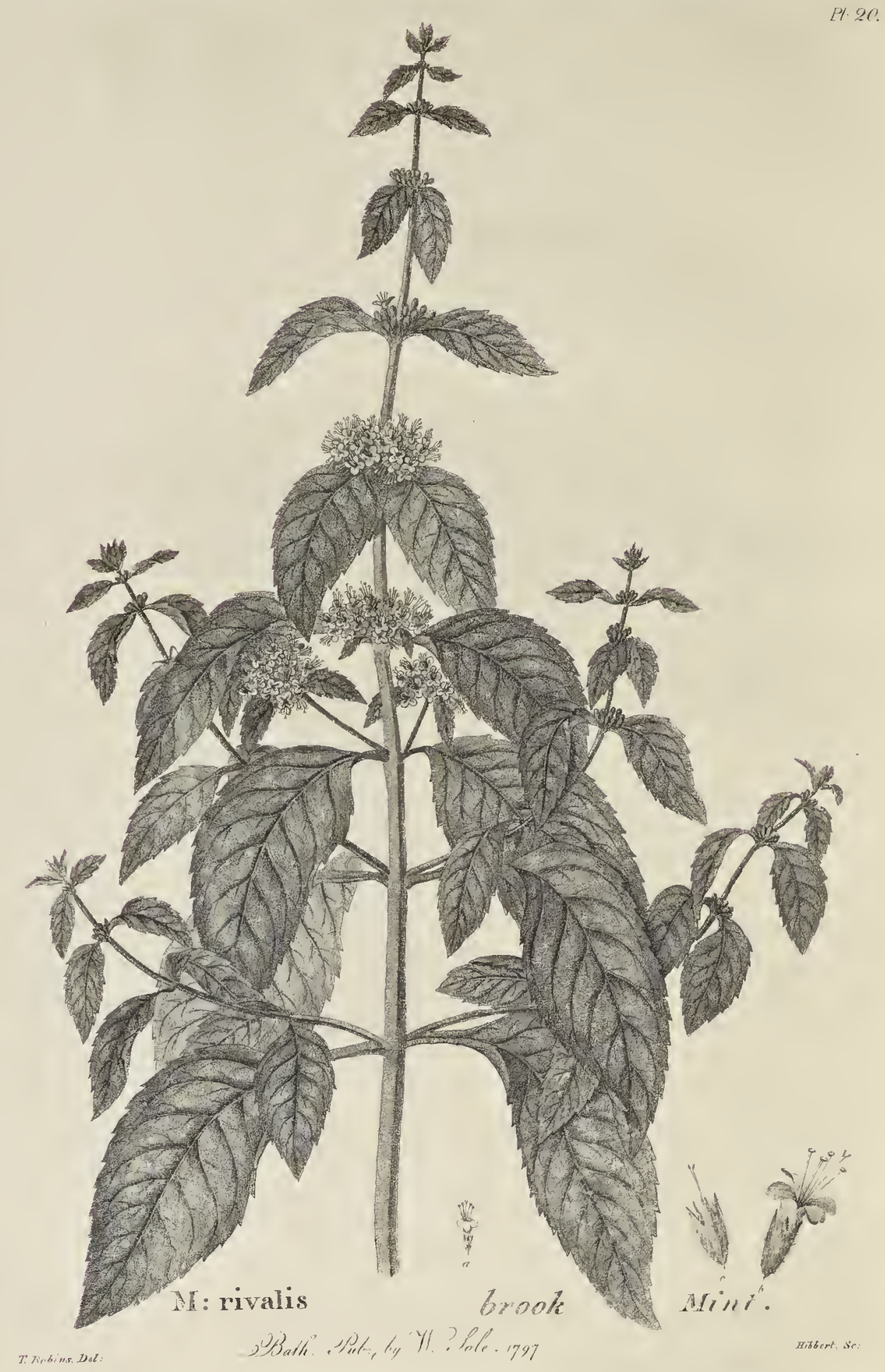


20. MENTHA RIVALIS.

Mentha verticillis lateralibus, aliquando pedunculatis, caule erecto ramofo hirfuto rubefcente, foliis latis ovatis acuminatis petiolatis argute ferratis, fuperne glabrioribus inferne villofis, nervis robuftioribus et ramofis, ftaminibus corolla longioribus. Menthæ fativæ odore graviore.

\section{Scropbularia nodofa facie.}

"Huic frmilem, hirfutie tamen foliorum difcrepantem invenit "D. Til. Bobart juxta rivulos quofdam ad latera montis Shot" over prope Oxonium. R. Syn.p. 232. de M. No. iv."

ß. Mentha rivalis-Calaminthæ facie et odore.

$\gamma$. Mentha rivalis-foliis inferioribus rotundioribus, fuperioribus concavis, caule inferne ramofo fuperne fimplice; ftaminibus corolla brevioribus. Serpylli odore.

f.' Mentha rivalis-foliis minoribus rotundioribus incanis, caule ramofo, ramis erectis longioribus villofis rubefcentibus. Mari odore.

Habitant in rivulis et pratis-bumidis.

Augufpo forent.

20. BROOK 
THIS Mint grows about three feet in height; the ftalk is fquare, upright, branched, and hairy, turning from a dark green to a reddifh colour as the fummer advances; the leaves ftand on foottalks, they are broad, ovate, and pointed, harply ferrated, and are hairy underneath, but almoft fmooth on the upper fides; the nerves are remarkably ftrong and branched, turning red towards autumn. The clufters of flowers are lateral and feffile towards the top of the ftalks, but the bottom clufters are pedunculated, ftanding on one common footftalk, as expreffed in the plate. The bloffoms are of a very pale pink colour, and are fhorter than the ftamens.

This plant has a coarfe, favage afpect, not unlike the common figwort: it has a heavy mixed goatifh fmell of fpear-mint.

This Mint has three varieties.

Variety the firf--Brook-Mint, refembling common calamint in face, habit, and fmell.

Variety the fecond-Brook-Mint, with broad round leaves at bottom, and concave ovate leaves on the upper part of the ftalks--the ftamens thorter than the bloffoms; the fmell is very pleafant, and like that of lemon-thyme.

Variety the third-Brook-Mint, with roundifh hoary leaves. The ftalk branched, and the branches are upright, and equal in height to the main ftalk; they are hairy and red, having a ftrong volatile fmell of marum.

The firft of thefe Mints grows in Locks-brook between Wefton and Twerton; the $\beta$ variety I found in wet meadows near Salifbury; the $\gamma$ variety grows in King's-Mead near Bath; the $\delta$ in ponds at SouthWraxall, Wilts, called Wraxall-Ponds.

They all blow in Auguft. 


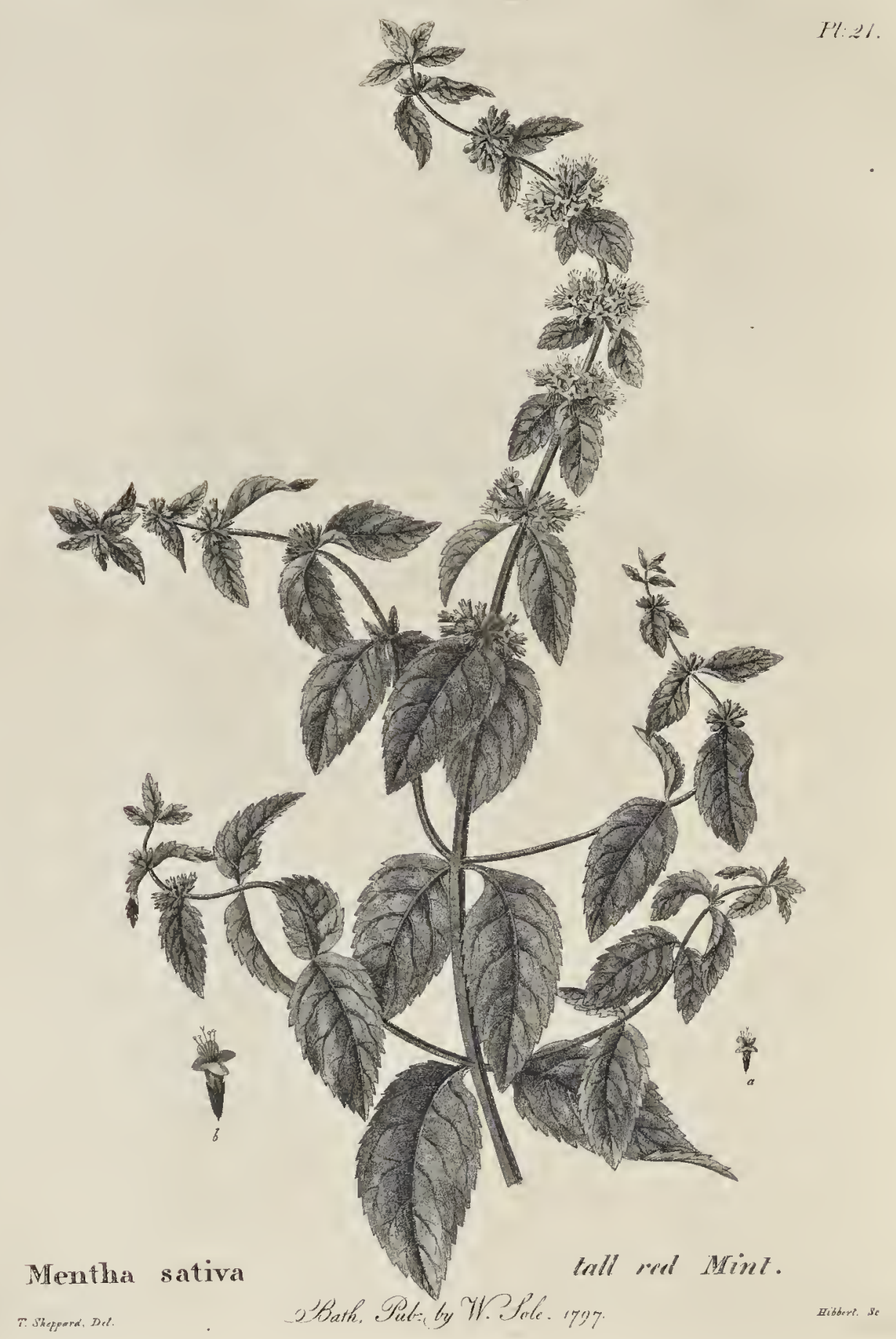


Mentha floribus verticillatis, foliis ovatis acutiufculis ferratis, ftaminibus corolla longioribus. Lin. Sp.P. p. 805 .

Mentha fativa prima. Fufch. cum ico.

Mentha crifpa verticillata, folio rotundiore.

7. B. Hiff. iii. p. 2 I6. ico. Fufch.

Mentha cruciata. Lob. icon. p. 507 .

Mentha crifpa verticillata. Matb. p. 526. ico.

C.B.Pin.p. 227 .

Park. p. 3I. ico. Lob.

Mor. H. O. Ject. xi. tab. 7. fig. 2.

Tourn. Inft. Men. iv.

Hill. B. H. p. 352. ico. Lob.

Mentha fativa rubra. Ger.em. p.68o. ico. Lob.

Mentha verticillata. $R$. Syn.p.232. No. iv.

Mentha fativa. Hud. F. A.p. 253 .

Habitat juxta rivulos et ad ripas fuviorum.

Septembri foret. 
THIS is the molt elegant plant of all the Mint tribe, growing from three to four feet in height; its ftalk is fquare, hard, and red, or rather of a dark chefnut colour; upright, except towards the top, where it becomes flowing, as do alfo the collateral branches, which are not very numerous; the main ftalk or leader runs on to a greater height than in all other mints, except the laft No. xx. with this difference, the leader in that runs upright and formal -in this, it is flowing, graceful, and eafy; the leaves ftand on thort foottalks, they are rigid, fomewhat crifped or curled, ovate, pointed, and deeply ferrated all the way down to the very point itfelf; the nerves of the leaves are red and a little hairy, as are alfo the edges of the leaves, but the furfaces are fmooth. The clufters of flowers fit in the bofoms of the leaves; the flowers are larger than thofe of any other mint, of a bright red colour, having the ftamens longer than the blofom.

John Bauhin's defcription of it is excellent, as indeed moft of his are.

I brought this plant twenty-three years ago from a brook in NorthWales. I alfo faw it in various waters in Colebrook-Dale, as well as in a wet place between Kidderminfter and Bridgenorth, Salops.

It is a late plant, and flowers in September. 



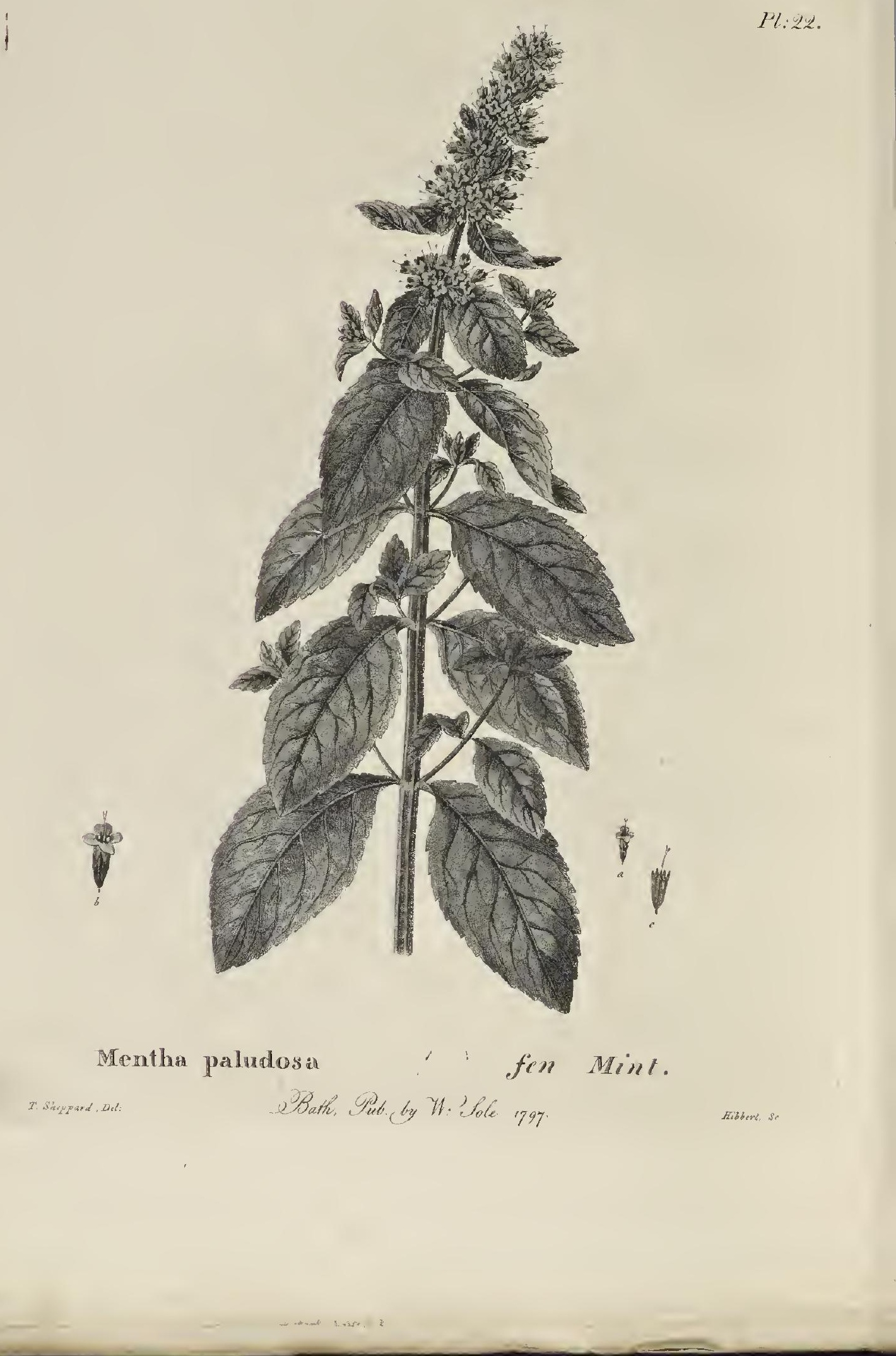


22. MENTHA PALUDOSA.

Mentha fpica capitato-verticillata; foliis oblongis crenatis petiolatis, lanuginofis, nervis rubris, caule erecto fubramofo villofo rubefcente, ftaminibus carolla æquantibus. Odore fragrantiffimo.

Mentha balfamita vel latifolia odorata, diutifime durat odor ejus fuavifimus. Mer. Pin. p. $77 \cdot$ ?

Habitat in aquofis paludofis.

Septembri floret. 
FEN Mint has an upright, green, hairy ftalk, growing about two feet in height; it is very lightly branched, and the branches are fhort, bearing one fmall head of flowers at their extremity. The leaves ftand on footftalks, they are notched at the edges, are foft and woolly; their nerves are red. The whirls of the flowers fit in the bofoms of the leaves to clofe together as to refemble a fpike; and what is particularly characteriftic in this plant, the ftalk terminates in a round head of flowers like the water mints, whereas all the other verticillate mints terminate in a neat rofeate knot of leaves. The flowers are large, and of a pale purple colour; the ftamens juft equal with the bloffom.

This plant has a moft agreeable fragrant fmell, refembling fweet marjoram. It is a late plant, and blows in the middle of September.

It grows in Holt-Fen, at Stretham, near Ely; alfo in a rivulet, by the fide of Awdry-caufey, near Hadingham, in the Ifle of Ely. 



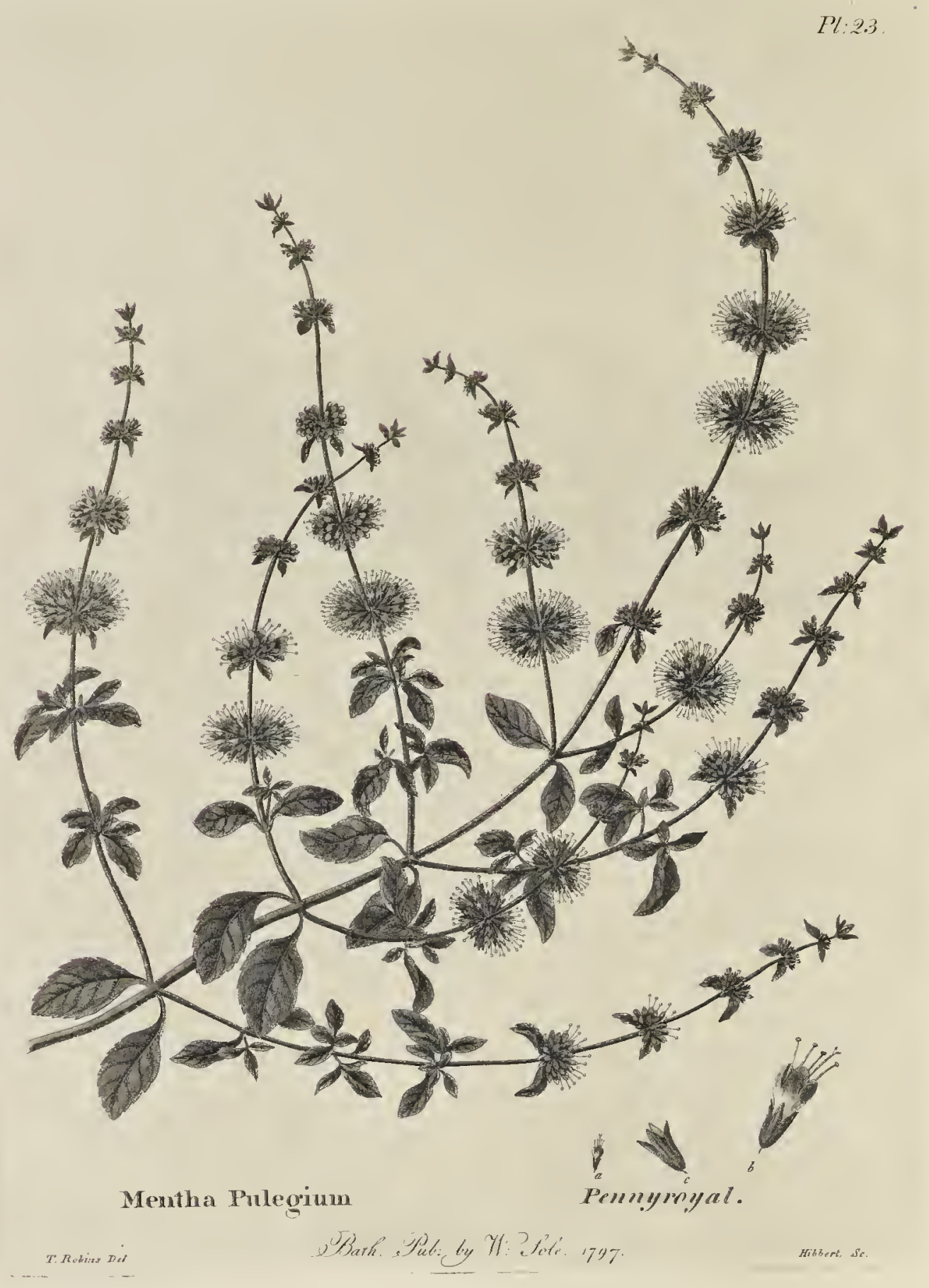


23. MENTHA PULEGIUM.

Mentha floribus verticillatis, foliis ovatis obtufis fubcrenatis, caulibus fubteretibus repentibus, ftaminibus corolla longioribus.

Lin. Sp. Pl. p. 807 .

Mentha Pulegium. Hud. F. A.p. 254.

Pulegium. F. B. H. iii. p. 256 .

Habitat in ericetis bumidis.

Septembri floret. 


\section{PENNY-ROYAL.}

THE main ftalk of this plant is fquare, like the reft of the mints, but is not fo deeply furrowed: it reclines on the ground, and fends forth numerous fmall branches, which are almoft round; the leaves are ovate, fmall, obture, and crenated. The rundles of flowers fit in the bofoms of the leaves at every joint; they are of a beautiful purple colour, and the ftamens are longer than the bloffom.

This ufeful plant is fo well known in all families, and treated of by fo many authors, that it is needlefs here to enlarge upon it; but it was neceffary to introduce it to perfect my defign, that of exhibiting a compleat fet of Plates of all the Britifh Mints hitherto difcovered.

The fine fpecimen from which this plate was taken, I gathered in the beginning of September, in a pond at the back of the Ball-faced Stag, Epping-Foreft, in 1793, where it grows abundantly, and in great luxuriance. 



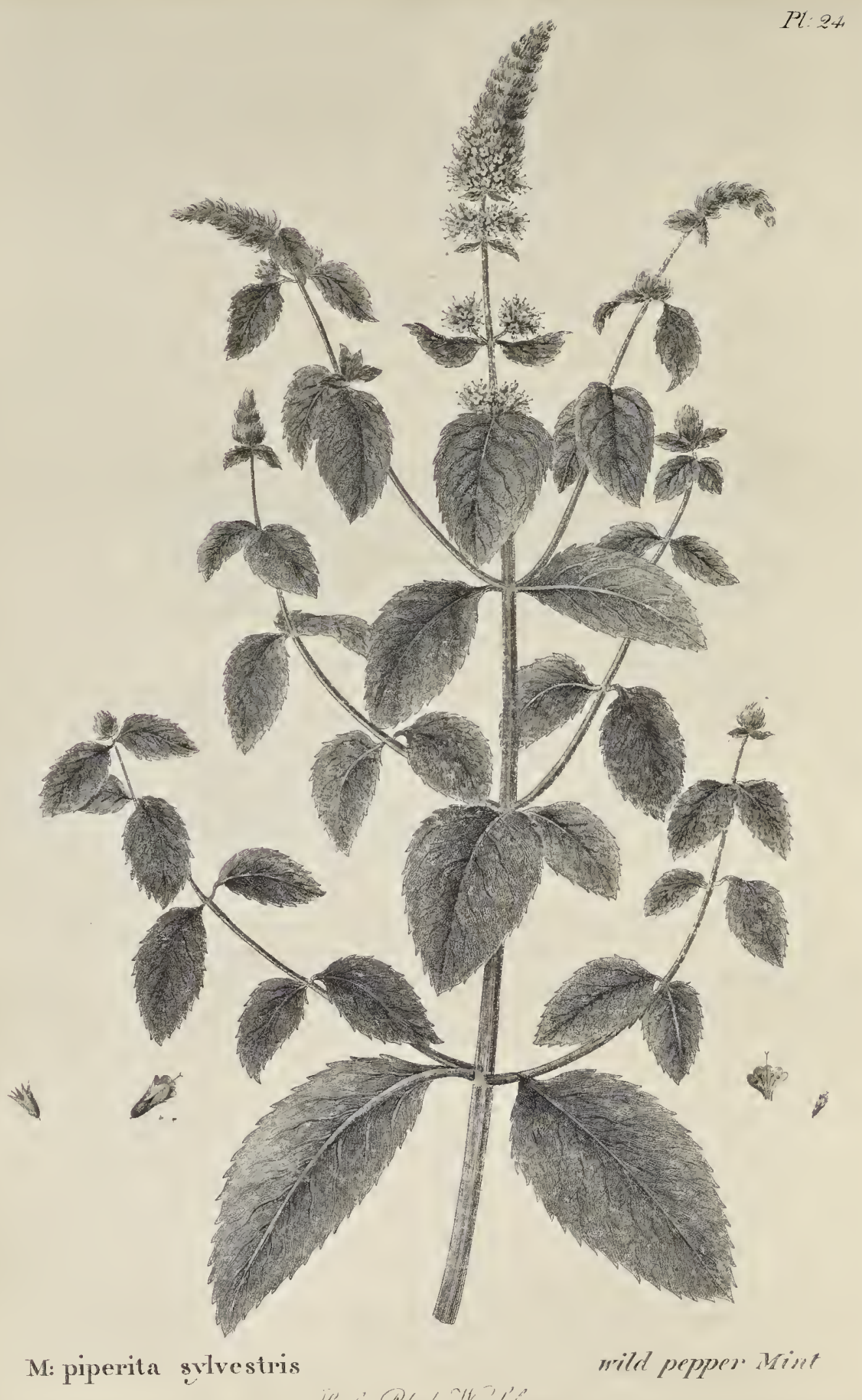

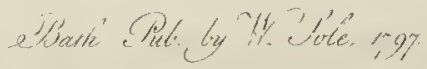


MENTHA SPICATA.

24. MENTHA PIPERITA SYLVESTRIS.

Mentha fpicis oblongis latioribus, interruptis, foliis latis ovatis acutis, petiolatis ferratis fubhirfutis, nervis albis, caule erecto rigido fubramofo, ex albido rubefcente, piperis odore gravi, ftaminibus corolla brevioribus.

Sub finem Septembris floret.

Habitat in aquofis. 
SPIKED MINT.

24. SAVAGE PEPPER-MINT.

THIS wild Pepper-Mint grows about three feet in height, (fometimes four.) The ftalk is hairy, upright, fquare, of a whitifh-green colour in Spring, but becomes reddifh towards autumn, and is branched in the manner of the true pepper-mint: its leaves are broad, ovate, pointed, ferrated, and a little hairy; the nerves are white; the ftamens are fhorter than the bloffom. It differs from the true pepper-mint in being much larger and coarfer, and having a difagreeable goatifh fmell of peppermint: the flowers alfo are paler, and more mixed with white: its whole afpect is very favage, and cultivation does not improve it.

This is a late plant, and blows about the latter end of September.

It grows in a fwampy place at Lyncomb Spa, and various other wet places in the neighbourhood of Bath. 
MENTHA AQUATICA TOMENTOSA.

Mentha fpicis glomeratis, caule erecto villofo non ramofo, foliis cordatoovatis ferratis petiolatis, incanis, mollioribus, ftaminibus corolla brevioribus: odore aromatico.

\section{HOARY WATER-MINT.}

THIS Mint grows about a foot and half in height; the ftalk is upright, very hairy, and not branched, unlefs quite at the top; its flowers are in very compact heads; the leaves are rather heart-fhaped than ovate, and are foft and woolly; the ftamens are fhorter than the bloffom: it has a fine aromatic fmell, and is, in its afpect, fo totally different from aquatica minor, and major, that it might with propriety be made a diftinet mint.

It grows upon Lanfdown, in the fpring-head of Locks-brook, (along with aquatica major and pip. officinalis) as well as in various other elevated fwamps about Bath. - It is a late plant, and does not blow before the latter end of September. 


\section{CORRIGENDA}

Page 5, line 1, for fpica oblonga, read fpicis oblongis; as it feldom occurs with a fingle fpike as Mr. Hudfon defcribes it.

11, 1. penult, for fuiortm, r. fitviornm.

22, 1. 9. for bint, r. mint.

35 , 1. ult, put a period before Hal

31,1 , ult. for Junit, r. Junio.

$35,1.2$, omit femicolon after folis, and place it after fufco.

佔 In pages 21 and 50 , to the quotation from Merret, which is cited to both plants, the mark of Interrogation, which I intended, is omitted-being doubtful, from his indefinite defcription, which it beft fuited; or whether it means either of them;-it is hoped therefore, that fome Botanift, whom it may fuit to fearch the way between Pemfey and Lewes, Suffex, will foon be able to find the plant and afcertain it. 

14 2.22

SNT

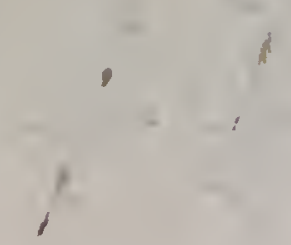


$1=$ 